\title{
Metal Nanoparticles: a Promising Treatment for Viral and Arboviral Infections
}

\author{
Kaminee Maduray ${ }^{1}$ (D) $\cdot$ Raveen Parboosing ${ }^{1}$ \\ Received: 20 July 2020 / Accepted: 28 September 2020 / Published online: 7 October 2020 \\ (C) Springer Science+Business Media, LLC, part of Springer Nature 2020
}

\begin{abstract}
Globally, viral diseases continue to pose a significant threat to public health. Recent outbreaks, such as influenza, coronavirus, Ebola, and dengue, have emphasized the urgent need for new antiviral therapeutics. Considerable efforts have focused on developing metal nanoparticles for the treatment of several pathogenic viruses. As a result of these efforts, metal nanoparticles are demonstrating promising antiviral activity against pathogenic surrogates and clinical isolates. This review summarizes the application of metal nanoparticles for the treatment of viral infections. It provides information on synthesis methods, size-related properties, nano-bio-interaction, and immunological effects of metal nanoparticles. This article also addresses critical criteria and considerations for developing clinically translatable nanosized metal particles to treat viral diseases.
\end{abstract}

Keywords Metal nanoparticle $\cdot$ Nanotherapeutics $\cdot$ Virus $\cdot$ Arbovirus $\cdot$ Treatment $\cdot$ Nanotechnology

\section{Introduction}

Nanotherapeutics has the potential to change the landscape of antiviral drug discovery and address issues related to resistance, emerging viruses, strain-specific targeting, and untreatable viral infections [1]. It uses nanoparticles (NPs) within the size range of $1-100 \mathrm{~nm}$ as a tool for drug delivery, diagnosis, and treatment of many infectious diseases [1-3]. Therapeutic NPs may be either inorganic (e.g., metal NPs) or organic (e.g., polymeric, liposomes, micelles, ferritin). Both types of NPs have been successful in pre-clinical studies and clinical settings for various medical conditions $[4,5]$. Recently, progress in utilizing metal NPs as antiviral agents has advanced rapidly owing to the ability of metals having a multi-target "attack" on viruses, with minimal impact on the subsequent development of resistance [1,6]. According to existing research, metal NPs have already proven to be active antiviral agents against human immunodeficiency virus (HIV), influenza virus, hepatitis virus, etc. $[1,6]$. This review aims to discuss and highlight the synthesis, properties, reported antiviral activities, and immunological impact of metal NPs.

Kaminee Maduray

madurayk@yahoo.com; madurayk@ukzn.ac.za

1 Department of Virology, University of KwaZulu-Natal/National Health Laboratory Service, Durban, South Africa

\section{Synthesis of Metal Nanoparticles}

There are wide arrays of physical, chemical, and biological methods to synthesize NPs [7]. In these methods, a threecomponent reaction of precursors, reducing agents, capping, or stabilizing agents is required [8]. Below is an overview of these methods.

\section{Physical Method}

The physical method for the synthesis of NPs include techniques such as ultraviolet (UV) radiation, microwave irradiation, sonochemical, thermal decomposition (thermolytic), photochemical, laser ablation, and radical induction [7, 9]. These techniques mainly utilize the top-down approach, prevent solvent contamination, and yield monodisperse NPs [9]. Synthesis proceeds from the evaporation of metal atoms to rapidly controlled condensation in which the metal atoms rearrange and aggregate to form small clusters of NPs [7]. Unfortunately, the abundant waste generated by physical methods for NP synthesis appears to be economically unfavorable [9].

\section{Chemical Method}

Chemical synthesis of metal NPs involves the bottom-up approach [7] with techniques such as the sol-gel method, microemulsion, hydrothermal synthesis, polyol synthesis, 
and chemical vapor synthesis [9]. Nanoparticles of welldefined size, dimension, composition, and structure are produced through chemical methods [10]. The synthesis mechanism entails reducing metal ions by chemical reductants or decomposition of metal precursors with extra energy in the presence of a stabilizer [7]. Inorganic and organic solvents are frequently used as reducing agents [11]. Stabilizing agents (i.e., organic solvents, synthetic, or natural polymers) are also used to prevent agglomeration of metal NPs. Alternatively, surfactants containing functionalities (e.g., thiols, amines, acids, and alcohols) may also act as a stabilizer and protect particles from sedimentation, agglomeration, or losing their surface properties [12]. Despite the appealing advantages of chemically synthesized NPs, there may be essential disadvantages such as environmental pollution, NP unsuitability for specific biomedical applications, and the use of toxic and non-biodegradable chemicals $[7,13]$.

\section{Biological Method}

Biological synthesis of metal NPs depends on the bottomup approach that employs unicellular and multicellular biological organisms (e.g., actinomycetes, bacteria, viruses, fungus, yeast, algae, and plants) [7, 14, 15]. Biogenic NPs are eco-friendly, quickly produced in large quantities, biocompatible, and of well-defined size and morphology $[7,16]$. Several controlling factors influence the size, morphology, nucleation, and stability of biogenic NPs. These factors include $\mathrm{pH}$, temperature, reactant concentration, synthesis time, etc. [17]. Microorganisms can produce metal NPs through either intracellular or extracellular routes. For example, metal ions transported into the microbial cell and trapped on the cell surface are enzymatically reduced to intracellularly and extracellularly synthesized NPs, respectively [14, 18]. Plant-based viruses such as cowpea chlorotic mottle virus (CCMV), cowpea mosaic virus (CPMV), brome mosaic virus (BMV), and tobacco mosaic virus (TMV) are used as biological templates to fabricate nanomaterial. The advantages of using plant viruses for nanomaterial synthesis include their small size, symmetric structure, ease of functionalization, monodispersity, and ability to self-assemble. Plant viruses are also non-infectious to humans and animals $[19,20]$. Biological extracts from leaves, flowers, stems, seeds, and roots of various plant species are also considered safe and environmental friendly for metal NP synthesis. In plant extracts, the existing metabolites (i.e., sugars, terpenoids, alkaloids, phenolic acids, proteins) are primarily responsible for the bioreduction of metal ions for the formation of stable NPs [7, 17]. In order to avoid environmental toxicity, cytotoxicity, and carcinogenicity, biological methods are preferred $[7,21]$.

\section{Size-Related Properties and Nano-bio-interaction of Metal Nanoparticles}

Metal NPs exhibit properties and catalytic activity that is size dependant and influenced by their metal ion [22]. These properties include physical [23], chemical, biological [24], mechanical [25], optical, magnetic [26], etc. The smaller the size of the NP, the higher the melting point, thermal conductivity performance, and viscosity [23]. Surface area and surface free energy are increased in smaller size NPs compared with the larger size, which results in changes in interatomic spacing [23]. The optical band gap energy increases with the decrease in particle size. Therefore, metal NPs in colloidal solution appear in a variety of colors that are size and shape related due to the surface plasmon resonance [23]. The presence of a higher specific surface area, heterogeneous catalysis [27-29], and metal ions, such as transitional [30, 31], in smaller sized NPs, is considered advantageous for catalytic support.

Furthermore, the biological activities (i.e., antibacterial, antiviral, antifungal, and anticancer) of NPs significantly increase with decreasing particle size [1]. Besides, the reduced particle size offers the possibility of intravenous administration of poorly soluble NPs without any blockade of the blood capillaries [23]. The biological activities of NPs also depend on their metal ions, shape, zeta potential, concentration, and method of preparation [1, 32]. In some instances, to stabilize and functionalize, metal NPs such as gold, silver, copper, palladium, and platinum ligands are used, due to their strong affinity towards the bare metal surfaces [33]. The binding affinity of ligands to cellular receptors increases proportionally with the size of the NPs because of the high protein content present on the surface of the NPs. The particle size is considered as the most crucial factor influencing cellular uptake and accumulation behaviors. Nanoparticles ranging from the size of 30-50 nm interact efficiently with cell membrane receptors and subsequently accumulate internally via receptor-mediated endocytosis. However, the optimal size for particle uptake is probably $50 \mathrm{~nm}$ since these sized particles offer a direct balance between the multivalent cross-linking of membrane receptors and the receptormediated endocytosis process [34]. In addition to size, the shape, composition, and surface charge of the NPs also influence cellular uptake and accumulation [32, 33]. Rod-shaped NPs tend to accumulate more than disc, spherical, cylinder, and cubed-shaped particles [32, 35]. Also, positively charged NPs achieve higher cellular uptake and accumulation internally by negatively charged cell membranes compared with neutral and negatively charged NPs [32]. 


\section{Antiviral Activity of Metal Nanoparticles}

The efficacy and antiviral activity of metal NPs depend on their size, shape, and metal ions. Notably, capped metal NPs present a significantly enhanced interaction with viruses and host cells than naked NPs [6]. The identified mechanisms of action for metal NPs can occur either inside or outside the host cells. These include the NP interacting with the gp120 proteins, competing with the virus for host cell-binding sites, inferencing with the viral attachment, and blocking the virus-host binding or penetration. Other potential mechanisms of action involve inactivating the virus particles before cellular entry, interacting with the viral genome or binding to the viral particles. Furthermore, the intracellular compartment of an infected cell is abundant in virally encoded and host cellular factors required for viral replication and production of progeny virions. Therefore, the interaction of metal NPs with these replication factors is another antiviral mechanism of action $[1$, $6,36]$.

Metal NPs, particularly silver and gold, have proven to exhibit antiviral activity against different viruses. The antiviral mechanism for gold NPs includes blocking of the gp120 attachment with CD4 to inhibit viral entry, whereas the antiviral mechanism of silver NPs involves inhibiting viral entry, attachment, or replication. For instance, silver NPs inhibit CD4dependant virion binding, merging, and pathogenesis by interacting with the viral gp120 in the cell-free and cellassociated virus. In double-stranded RNA viruses, the silver NPs, after interaction with the viral genome, will inhibit viral replication $[1,6,36]$. Other metal NPs such as copper block the virus attachment, inhibit virus-cell binding, and viral entry into target cells. Copper NPs also destroy the viral genome and disrupt the capsid. Zinc NPs interfere with viral DNA polymerase activity resulting in viral replication inhibition. The inhibition of viral entry to the target cells depends on the ability of zinc NPs to bind to the virions. Iron NPs preferentially bind to the virus to inhibit it from binding to the cells. However, selenium NPs effectively protect the target cells from apoptosis caused by the infection of the virus $[1,6,36]$.

\section{Immunological Effects of Metal Nanoparticles}

Metal NPs can interact with immune cells, such as macrophages, monocytes, dendritic cells, and lymphocytes, and potentially elicit modified immune responses [37]. However, the capacity of any metal NP to elicit an immune response depends on their physicochemical properties such as size, size distribution, surface area and reactivity, crystallinity, aggregation in a suitable medium, composition, surface coating, method of synthesis, and impurities [38, 39]. These immune responses include immunostimulation, immunosuppression, hypersensitivity, immunogenicity, and autoimmunity, comprising of both innate and adaptive immune responses $[38,40]$. Therefore, the unexpected interaction with the immune system and modulation of the immune function by NPs can be beneficial or detrimental. In the future, metal NPs can be designed to be immunomodulatory to serve specific functions (e.g., vaccine adjuvants, anti-inflammatory, proinflammatory drugs) and improve the nanotreatment of infectious diseases. However, engineered immunomodulatory or conventional metal NPs that modify the immune system must reconcile with concerns about biocompatibility and immunotoxicity of nanomaterial [40-42].

Elevated cytokine levels, particularly pro-inflammatory, upon treatment with NPs have been associated with immunotoxicity and low therapeutic efficacy. At times, the elevation of both pro-inflammatory (e.g., IL- 6 and TNF- $\alpha$ ) and anti-inflammatory (e.g., IL-10) cytokine levels because of an unregulated innate immune response (i.e., cytokine storm) has made it more difficult to understand the underlying mechanisms of immunotoxicity $[40,43]$. Therefore, metal NP purification is essential for removing iron contaminants and endotoxins that contribute to stimulating cytokine storms and exaggeration of inflammatory reactions. Nanoparticles may also generate large quantities of ROS that can trigger TNF receptors, resulting in the release of pro-inflammatory cytokines through the activation of the NF- $\mathrm{kB}$ transcription factor. In some cases, the inflammatory effect and release of cytokines can be inhibited by an enzyme, catalase, that protects against oxidative stress by catalyzing hydrogen peroxide decomposition into oxygen and water [43]. Nonetheless, a better understanding of the underlying interactions between metal NPs and the immune system is essential for the development of biocompatible, non-immunotoxic, and non-immunogenic nanomaterials for a variety of biomedical applications.

\section{Antiviral Potential of Metal Nanoparticles Against Different Viruses}

In recent years, there have been several reports on the antiviral activity of metal NPs, which are discussed below in detail and summarized in Table 1.

\section{Adenoviruses}

Human adenoviruses (HAdVs) are ubiquitous DNA viruses that possess a broad spectrum of pathogenicity. This virus is also associated with respiratory, gastrointestinal, urinary, and ocular illnesses in adults, infants, and immunocompromised individuals [44, 45]. Clinical treatment of HAdV infections focuses on alleviating the patient's symptoms or the use of antiviral drugs, such as ribavirin and cidofovir for HAdV severe infections in immunocompromised individuals [44, 45]. Despite the encouraging treatment outcomes of cidofovir, 


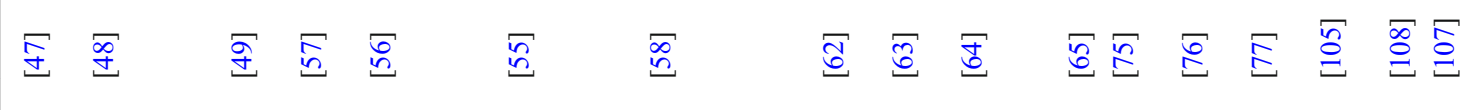

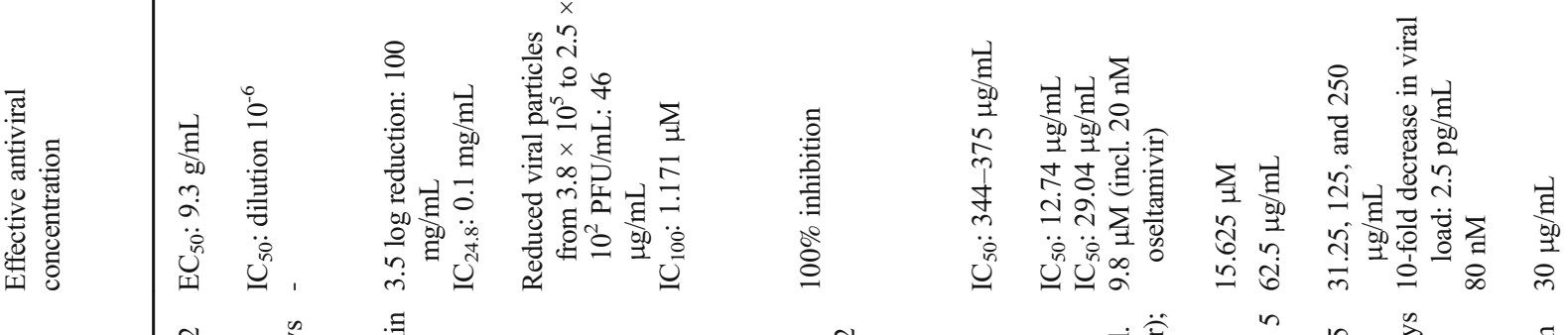

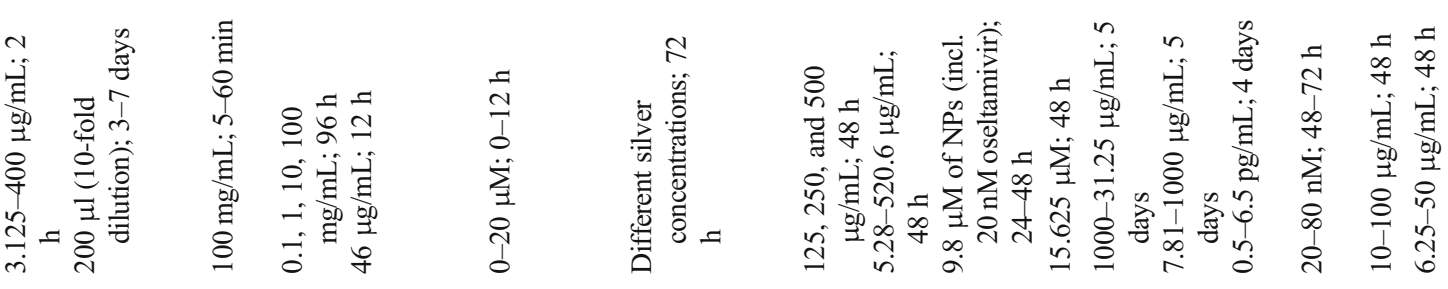

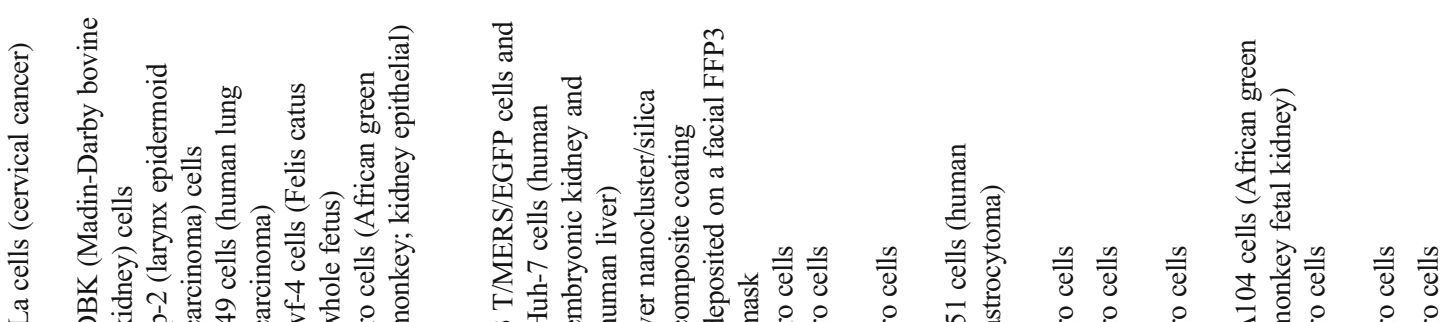

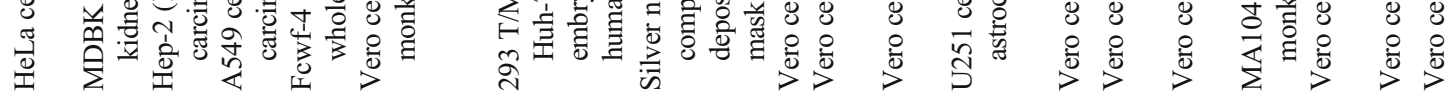
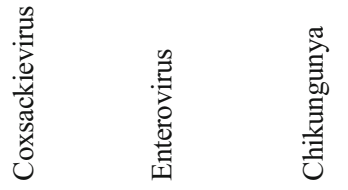


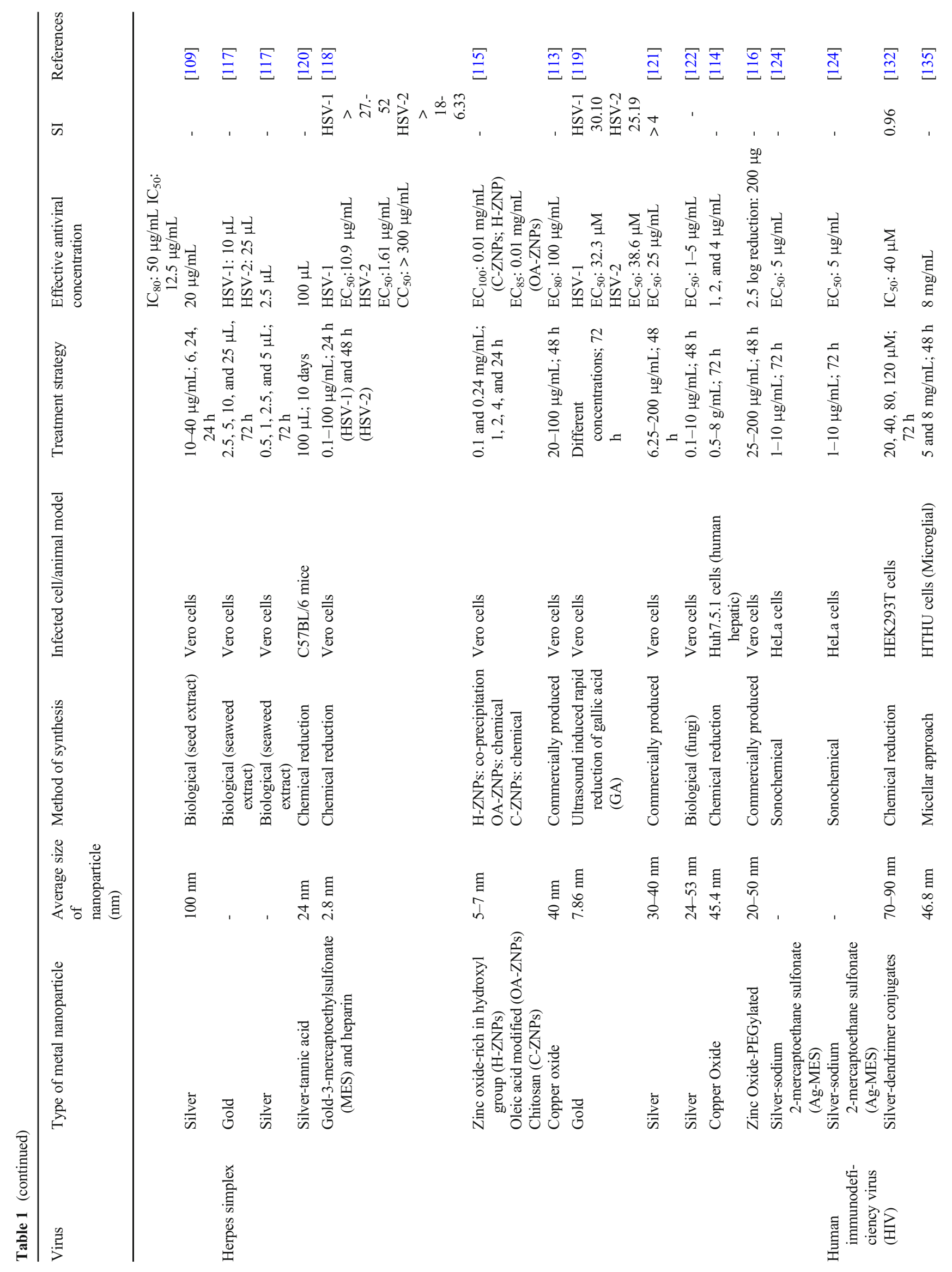




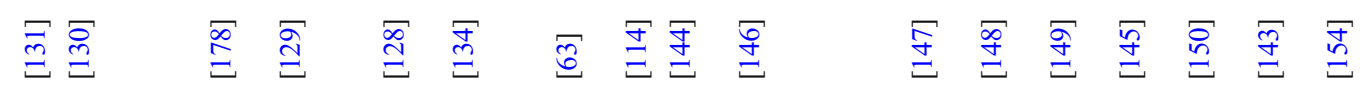

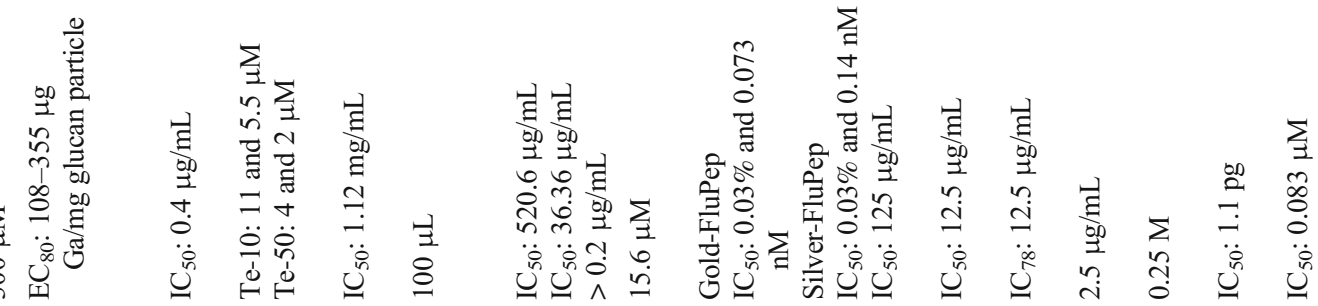

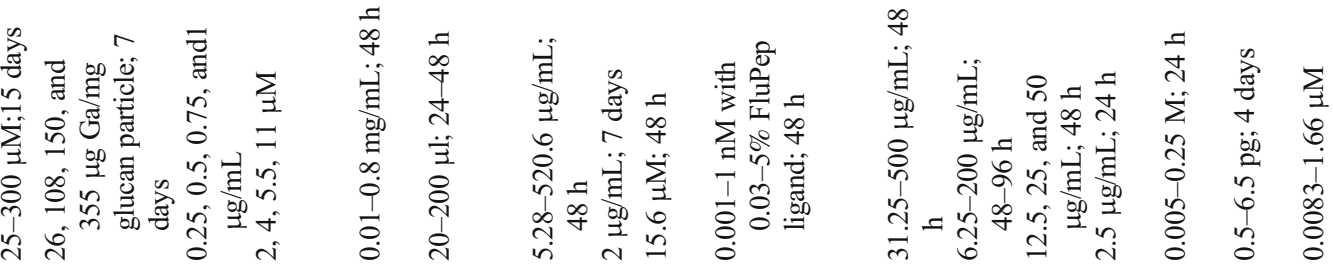

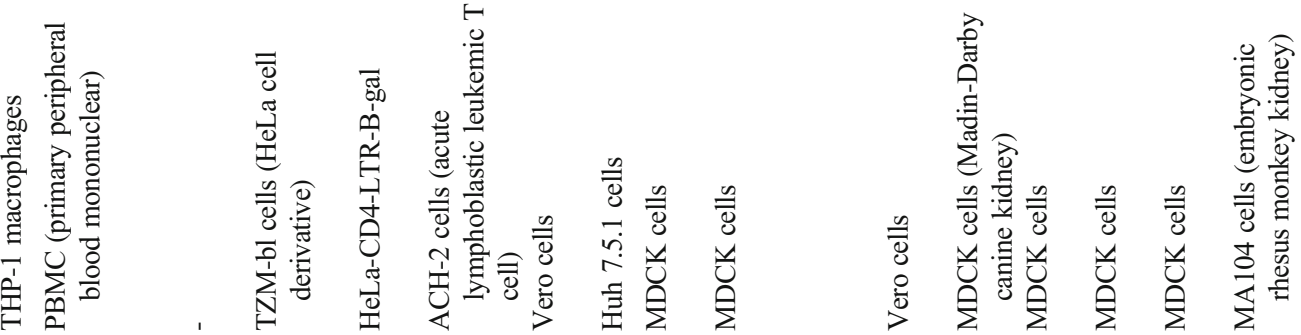

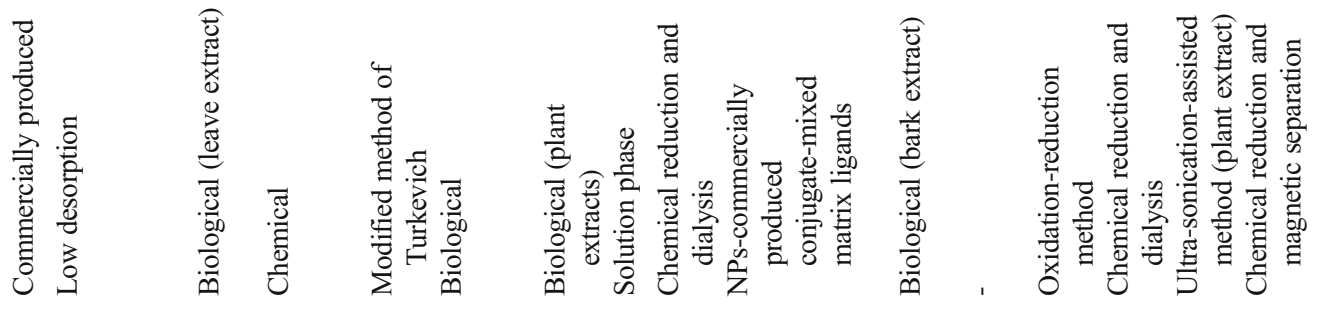

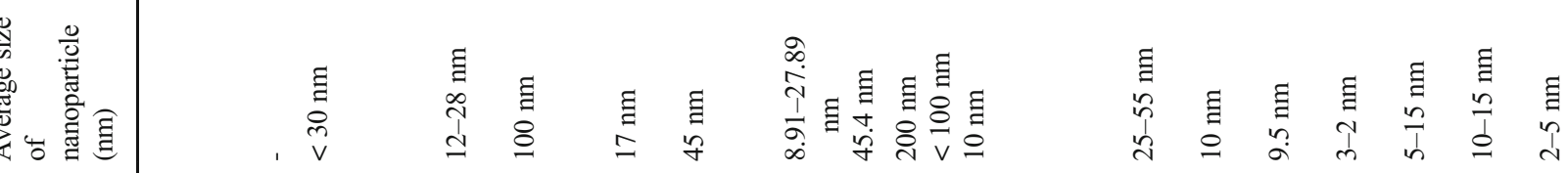

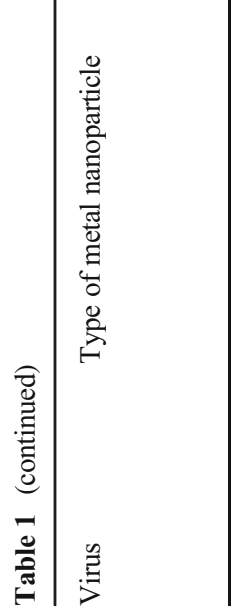

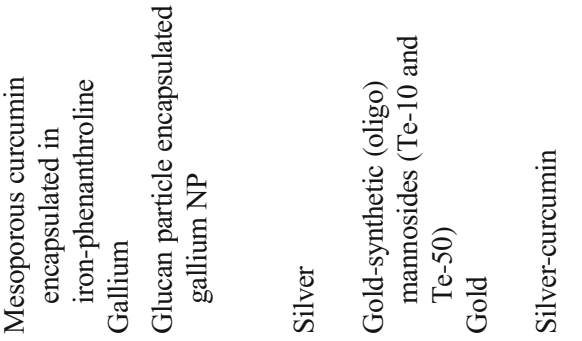

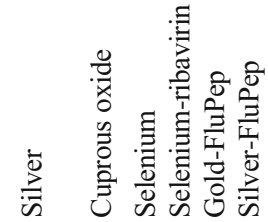

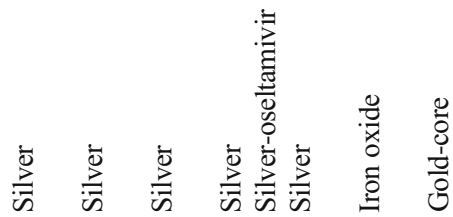

总

.气 


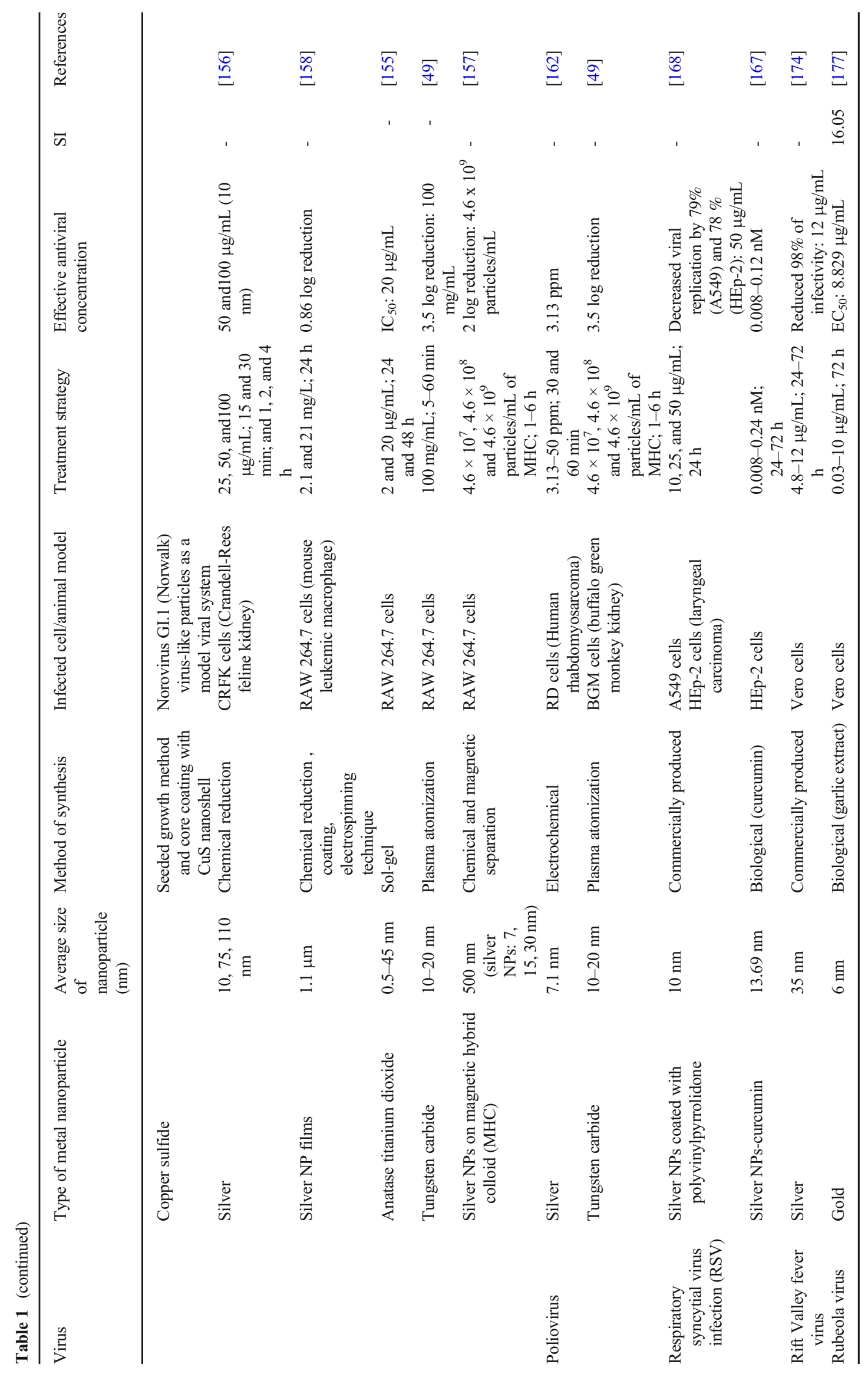


therapeutic use is limited due to its low bioavailability and nephrotoxic effects $[44,46]$.

Silver, gold, and tungsten carbide NPs have been evaluated as potential therapeutics for the treatment of human adenovirus infections. Chen et al. [47] reported that silver NPs exhibited dose-dependent inhibitory activity on adenovirus in vitro. The half-maximal effective concentration $\left(\mathrm{EC}_{50}\right)$ of the studied silver NPs against virally infected cells after $2 \mathrm{~h}$ of incubation was $9.3 \mathrm{~g} / \mathrm{mL}$, and this concentration was not toxic to uninfected cells [47]. Lysenko et al. [48] synthesized two types of gold NPs as antiviral agents against adenovirus. Gold NPs coated with silicon dioxide shells and gold-silicon dioxide carrier NPs reduces the associated toxicity effects of gold ions. Both types of NPs showed to be effective against adenovirus with $96 \%$ and $100 \%$ inhibition. Pfaff et al. [49] showed that tungsten carbide NPs could reduce the infectivity of adenovirus type 5 by $50 \%$ in $15 \mathrm{~min}$. These NPs also displayed significant antiviral activity against other types of viruses such as modified vaccina virus Ankara (MVA), poliovirus, and norovirus. In this regard, these NPs might be utilized as an effective nanotechnology-based disinfectant [49].

\section{Coronavirus}

Coronavirus $(\mathrm{CoV})$ is an enveloped positive-sense RNA zoonotic virus [50]. In humans, it consists of a wide range of viruses contributing to the common cold and severe respiratory diseases such as the Middle East respiratory syndrome (MERS), severe acute respiratory syndrome (SARS), and novel coronavirus [51]. Epidemics of coronavirus emerge unexpectedly and spread quickly, causing an unusually high death toll, threatening human health and daily activities. These include the SARS-CoV and MERS-CoV epidemic in 2003 and 2012, respectively [51]. To date, the coronavirus disease 2019, (COVID-19) pandemic, is accelerating in infection and mortality rates worldwide [51]. The causative agent is severe acute respiratory syndrome coronavirus 2 (SARSCoV-2), with no specific treatment or vaccine found to be successful in treating infected individuals [51].

Nanotechnology has received considerable attention from scientific communities as a vaccine [52], treatment, diagnostic, and protective source to combat coronavirus [51, 53, 54]. A recent study by Huang et al. [55] validated a new gold nanorod-based HR1 peptide inhibitor (PIH-gold NRs) for MERS. At a concentration of $1.171 \mu \mathrm{M}$, PIH-gold NRs exhibited a 10-fold higher inhibitory activity than treatment with the peptide inhibitor only. Besides, at the same concentration, PIH-gold NRs completely inhibited cell fusion. This study further concluded that their newly developed PIH-gold NRs are biocompatible, biostable, and a highly effective antiMERS agent [55]. Du et al. [56] validated that glutathionecapped silver sulfide nanoclusters, $5.3 \mathrm{~nm}$ in size, are active against porcine epidemic diarrhea virus (PEDV), a coronavirus model. Treatment with a concentration of 46 $\mu \mathrm{g} / \mathrm{mL}$ for $12 \mathrm{~h}$ reduced plaque formation unit (PFU) from $3.8 \times 10^{5}$ to $2.5 \times 10^{2}$ per $\mathrm{mL}$. This study also proposed that treatment with the studied nanoclusters inhibited PEDV infection by activating the production of IFN-stimulating genes (ISGs) and pro-inflammatory cytokines. These nanoclusters also prevented viral replication and budding [56]. Therefore, these results have paved the way for further research on other metal NPs (i.e., copper, zinc) to combat coronaviruses infections, such as COVID-19.

Researchers have also investigated the application of silver NPs to decrease the transmission of viruses in personal protection equipment. Graphene-silver nanocomposites, at a concentration of $0.1 \mathrm{mg} / \mathrm{mL}$, inhibited $24.8 \%$ of infection by $4.7 \times 10^{4} \mathrm{TCID}_{50}$ (tissue culture infective dose required to kill $50 \%$ of the infected host) per $\mathrm{mL}$ of feline coronavirus [57]. Silver nanocluster silica composite sputtered coating applied to the facial FFP3 mask, ultimately reduced the titer of SARS-CoV-2 to zero [58]. Therefore, applications of NPs for personal protection equipment to decrease the transmission of coronaviruses and other viruses require further consideration.

\section{Coxsackievirus and Other Enteroviruses}

Coxsackievirus is an enterovirus, associated with the hand, foot, and mouth disease (HFMD), acute febrile illness in children, acute localized exanthema, myocarditis, hepatitis, and pancreatitis. Intrauterine infection and feral demise are also coxsackievirus-related infections during pregnancy [59, 60]. There are no specific antiviral therapies available. Therefore, the preferred treatment regimen includes medication to reduce symptoms and manage pain [59, 61]. Salem et al. [62] found that silver NPs with aqueous leave and fruit extracts from Ricinus communis inhibited Coxsackievirus at half-maximal inhibitory concentrations $\left(\mathrm{IC}_{50}\right)$ of 344 to $375 \mu \mathrm{g} / \mathrm{mL}$, possibly by acting as a fusion inhibitor. Haggag et al. [63] found that silver NPs with extracts from Lampranthus coccineus showed significant antiviral activity against Coxsackievirus at an $\mathrm{IC}_{50}$ of $12.74 \mu \mathrm{g} / \mathrm{mL}$. Furthermore, molecular docking findings predicted that an existing interaction between the biosynthesized NPs and Coxsackievirus $3 \mathrm{c}$ protease was responsible for the antiviral activity [63].

Selenium NPs were found to be active against enterovirus. Also, selenium NPs conjugated with oseltamivir inhibited enterovirus activity by reducing the production of ROS in human astrocytoma cells [64]. Li et al. [65] reported that selenium NPs inhibited the Jun amino-terminal kinase (JNK) signaling pathway, $\mathrm{p} 38$ kinase, and ROS production, resulting in reducing the viral protein synthesis and viral yield [66] and controlling ROS [67], which promoted antiviral activity against enterovirus. 


\section{Chikungunya Virus}

Chikungunya is a febrile disease caused by positive-sense single-stranded RNA alphavirus in the Togaviridae family. The virus is transmitted primarily by the mosquito belonging to the Aedes genus $[68,69]$. The common symptoms include muscle pain, headache, nausea, fatigue, and rash. The virus can cause acute, subacute, or chronic disease. Complications such as eye, heart, neurological, and gastrointestinal are commonly seen in infants, adults with comorbidities, and elderly patients [70-72]. Occasionally, co-infections with other mosquito-borne viral infections such as dengue and Zika present an additional challenge during differential diagnosis and treatment [73]. There are no specific antivirals or vaccines available for chikungunya, except for symptomatic treatment [70]. Alternatively, control of the mosquito vector becomes the primary target for the effective management of chikungunya [74].

Metal NPs have also been reported to have potential antiviral and larvicidal activity against vector-borne diseases such as chikungunya. For example, Kaushik et al. [75] investigated silver NPs capped with plant extracts (Carica papaya), as an antiviral agent for chikungunya infection using Vero cells. The reported maximum non-toxic dose (MNTD) and $1 / 2$ MNTD of silver NPs were $125 \mu \mathrm{g} / \mathrm{mL}$ and $62.5 \mu \mathrm{g} / \mathrm{mL}$, respectively. A concentration of $62.5 \mu \mathrm{g} / \mathrm{mL}$ of NPs induced $52 \%$ inhibition against chikungunya virus [75]. Similarly, the anti-chikungunya activity of silver NPs capped with extracts from Andrographis paniculata was reported, with a concentration of $31.25 \mu \mathrm{g} / \mathrm{mL}$ (MNTD) and $15.63 \mu \mathrm{g} / \mathrm{mL}(1 / 2 \mathrm{MNTD})$ exhibiting $75-100 \%$ and $25-49 \%$ inhibition of cytopathogenic effects (CPE) respectively [76]. Treatment with low concentrations of zinc oxide $(2.5 \mathrm{pg} / \mathrm{mL})$ displayed antichikungunya activity by decreasing levels of viral RNA transcripts within $24 \mathrm{~h}$ of infection as revealed by RT-PCR [77]. Another study reported that copper oxide NPs synthesized using leaf exacts from Tridax procumbens displayed larvicidal activity against the chikungunya vector at a median lethal dose $\left(\mathrm{LD}_{50}\right)$ of $4.209 \mathrm{mg} / \mathrm{L}$ [78]. Silver NPs capped with plants extracts from Ambrosia arborescens, paddy straw, Rhazya stricta, Daemia extensa, Solanum mammosum L. pilaquinga, and Hymenodictyon orixense demonstrated larvicidal activity against the chikungunya vector at a $\mathrm{LD}_{50}$ of $0.28 \mathrm{ppm}$ [79], $13.625 \mathrm{ppm}$ [80], $30.66 \mu \mathrm{g} / \mathrm{mL}$ [81], $3.842 \mathrm{ppm}$ [82], $0.06 \mathrm{ppm}$ [83], and $17.10-20.08 \mathrm{mg} / \mathrm{mL}$ [84] respectively.

\section{Dengue Virus}

Dengue is a mosquito-borne endemic infectious disease of tropical and subtropical countries, rapidly becoming a global burden [85]. The dengue virus causes symptoms of varying degrees, ranging from mild asymptomatic dengue fever to severe dengue hemorrhagic fever and dengue shock syndrome, which may be fatal. To date, there are no effective antiviral drugs and vaccine candidates for dengue. Therefore, clinical management focuses on supportive treatment [85-87].

Studies have investigated the larvicidal activity of copper [78, 88], selenium [89], gold [90-92], and silver [93-102] NPs, and demonstrated their potential for inactivating the significant mosquito vectors (genus Aedes) of dengue [103, 104]. Paul et al. [105] analyzed the antiviral activity of gold NPs conjugated with small interfering RNA against the dengue virus. These NPs were able to enter the infected Vero cells and significantly reduce dengue virus serotype 2 (DENV-2) replication and infectious virion release under both pre- and postinfection conditions [105]. Quach et al. [106] reported on a novel subunit vaccine with a hybrid containing gold NPs and domain III of the viral envelope protein (EDIII) for dengue virus. In this study, anti-EDIII antibodies were induced into mice immunized with the hybrid gold NPs in a size and concentration-dependent manner [106]. Also, biosynthesized silver NPs using algae (Centroceras clavulatum), plant (Bruguiera cylindrical), and seed (Moringa oleifera) extracts showed anti-dengue activity at concentrations of $12.5-50,30$, and $20 \mu \mathrm{g} / \mathrm{mL}$, respectively [107-109].

\section{Herpes Simplex Virus}

Infection with herpes simplex virus, known as herpes, can be due to either herpes simplex virus type 1 (HSV-1) or herpes simplex virus type 2 (HSV-2). Both types are highly prevalent within the human population [110]. HSV-1 is mainly transmitted orally (oral herpes), whereas HSV-2 through oralgenital contact (genital herpes) [111]. Herpes virus infections are recurrent, lifelong, and incurable. Current antiherpes therapies (i.e., pharmacological, topical, systemic, or laser therapy) are known to prevent or shorten outbreaks and reduce the risk of transmission [112]. However, individuals with immunosuppression (due to human immunodeficiency virus (HIV) malignancies or transplantation) may develop HSV-1 and HSV-2 variants that are resistant to the current antiherpetic therapies [110].

Various nanomaterials, e.g., copper [113, 114], zinc [115, 116], gold [117-119], and silver [117, 120-122], have proven to be effective against herpes. Silver NPs tend to block herpesvirus entry into the host cell by competing for binding to cellular heparin sulfate via the sulfonate end group [123, 124], whereas zinc NPs inhibit viral DNA polymerase activity [116]. Copper NPs generate ROS to inactivate the HSV by oxidation of viral proteins or degradation of the viral genome [113]. Mercapto-ethyl sulfonate gold NPs (with or without surfactant) inhibited HSV-1 and HSV-2 in cell culture [117-119]. 


\section{Human Immunodeficiency Virus}

Incurable infectious diseases such as HIV are among the leading causes of death worldwide $[125,126]$. There are currently more than 30 approved antiretroviral drugs for the treatment of HIV infection, which includes 13 singletablet drug combinations of two or more antiretroviral drugs. Antiretroviral therapies (ART) can suppress HIV replication to undetectable levels, provided that patients adhere to treatment regimens [127]. However, globally, HIV remains a challenge despite significant progress in decreasing its incidence and mortality rate [126].

Various metal NPs such as iron, silver, gallium, and gold have shown to be active against HIV, resulting in decreased viral growth and replication [1]. Silver NPs bind to gp120 protein to inhibit CD4-dependant virion binding, fusion, and infectivity. Gallium NPs interact with the CD4 membrane, thereby inhibiting HIV infection in macrophages. Gold NPs inhibit virus entry and are virusneutralizing agents [1]. Vijayakumar and Ganesan (2012) [128] reported that stabilized gold NPs were effective against the M-tropic, T-tropic, dual tropic, and resistant HIV isolates with a $50 \%$ inhibition concentration of 1.12 $\pm 0.05 \mathrm{mg} / \mathrm{mL}$. Marradi et al. [129] synthesized gold NPs coated with synthetic oligomannosides (Te-50 and Te-10), present in gp120, to stimulate 2G12-mediated neutralization of HIV infection in TZM-bl reporter cells. The NP formulations at concentrations of $2 \mu \mathrm{M}(\mathrm{Te}-50)$ and $5.5 \mu \mathrm{M}(\mathrm{Te}-10)$ neutralized $50 \%$ of the HIV-1-infected cells [129]. Glucan conjugated with gallium NPs inhibited HIV in macrophages ( $>80 \%$ inhibition with formulations containing 108-355 $\mu \mathrm{g}$ gallium $/ \mathrm{mg}$ glucan particles) [130]. Another study has revealed that gallium NPs suppress the co-infection of HIV and tuberculosis [131]. Silver NPs $(12-28 \mathrm{~nm})$ with leaf extracts from mangrove Rhizophora lamarckii also inhibited HIV-1 reverse transcriptase activity with the $\mathrm{IC}_{50}$ value of $0.4 \mu \mathrm{g} / \mathrm{mL}$ [178]. Individually, silver NPs conjugated with either anionic linear globular dendrimer [132] or sodium 2-mercaptoethane sulfonate (Ag-MES) [124] inhibited HIV replication efficiently.

Curcumin has been known to have many therapeutic benefits that now includes antiviral activity [133-135]. Curcumin-stabilized silver NPs with a diameter of 45 $\mathrm{nm}$, demonstrated non-toxic antiretroviral and immunomodulatory effects on $\mathrm{ACH}-2$ cells latently infected with HIV-1 [134]. Another study determined that multifunctional mesoporous curcumin encapsulated in ironphenanthroline nanoclusters, with a particle size of 46.8 $\mathrm{nm}$, significantly decreased the expression of HIV-p24, TNF- $\alpha$ factors, IL- 8 , and nitric oxide by $41 \% 61.2 \%$, $41 \%$, and $50.2 \%$, respectively [135].

\section{Hepatitis}

Globally, viral hepatitis has been confirmed as one of the leading causes of death, liver diseases, and disability. These liver diseases include cirrhosis, hepatocellular cancer, decompensated disease, and extrahepatic manifestations $[136,137]$. Currently, hepatitis $\mathrm{C}$ is curable if detected early with the aid of direct-acting antiviral therapies. Hepatitis B is often manageable through oral nucleos(t)ide therapies with highresistance barriers. Significant advances in the management of hepatitis D infection are occurring [136]. However, a cure for viral hepatitis remains elusive, in the setting of viral genetic persistence within the hepatocyte nucleus, even with suppressive antiviral therapy [136]. Therefore, a possible cure and future therapeutic options must consider the targeting of multiple viral replication pathways in order to eliminate viral hepatitis as a public health threat [136].

Silver NPs have shown renewed promise in their ability to inhibit hepatitis replication. In a study by $\mathrm{Lu}$ et al. [138], different size silver NPs $(10,50$, and $80 \mathrm{~nm})$ were evaluated as an antiviral agent against hepatitis B. In this study, the silver NPs, $10 \mathrm{~nm}$ in size, produced $38 \%$ and $80 \%$ viral inhibition with a concentration of $5 \mu \mathrm{M}$ and $50 \mu \mathrm{M}$ respectively, while the silver NPs of $50 \mathrm{~nm}$ were slightly more potent with $53 \%$ and $92 \%$ inhibition at a concentration of $5 \mu \mathrm{M}$ and $50 \mu \mathrm{M}$, respectively [138]. Haggag et al. [63] have recently analyzed biosynthesized silver NPs with extracts from Lampranthus coccineus and Malephora lutea against hepatitis A. This study reported that these NPs exhibit antiviral activity against hepatitis $\mathrm{A}$ and protect the host cell from viral infectivity [63]. Hang et al. [114] also indicated that copper NPs blocked hepatitis infection at the entry and attachment stages. Therefore, these findings suggest that silver and copper NPs may have novel roles in treating chronic hepatitis patients.

\section{Influenza}

Influenza, commonly known as the flu, consists of three types of viruses (A, B, and $\mathrm{C}$ ) that belong to the Orthomyxoviridae family. These are enveloped and negative-strand RNA viruses [139]. Influenza occurs globally as local outbreaks or seasonal epidemics [140]. In the past 100 years, four influenza pandemics have occurred: H1N1 Spanish influenza in 1918, H2N2 Asian influenza in 1957, H3N2 Hong Kong influenza in 1968, and H1N1 swine influenza in 2009. In 1977, the H1N1 virus re-emerged but did not cause a pandemic [140]. However, since 1918, a novel influenza virus emerged from each pandemic, either directly from an avian host (1918), by reassortment between an avian virus and a circulating human strain (1957 and 1968), or through influenza virus reassortment in pigs (2009) and spread to the human population, causing considerable morbidity and mortality [140-142]. 
Annual vaccination remains the critical mode of prevention against seasonal influenza; however, the vaccines are effective only if the antigenic matching of the vaccine strains corresponds with the circulating virus strains [142]. The antiviral drugs currently available against influenza viruses are amantadine, rimantadine, zanamivir, oseltamivir, peramivir, and baloxavir marboxil. Antiviral resistance, influenza A virus infections, and control of future influenza pandemics are still an ongoing global concern [142].

Several studies have demonstrated the efficacy of metal NPs as potential antiviral agents against the influenza virus [143]. Iron oxide NPs showed in vitro inhibition (50\%) against the H1N1 influenza A virus strain using a low concentration of $1.1 \mathrm{pg}$ [143]. Lin et al. [144] analyzed the antiinfluenza effects of selenium NPs and their conjugate with a broad-spectrum antiviral drug, ribavirin (RBV). Influenza infected Madin-Darby canine kidney (MDCK) cells exposed to no treatment, RBV only, selenium NPs, and selenium NPs with RBV achieved a cell viability of 48.4\%, 68.5\%, 65.2\%, and $80.6 \%$, respectively [144]. In a study by Li et al. [145], silver NPs were used to co-deliver oseltamivir to inhibit the H1N1 influenza virus activity through ROS-mediated signaling pathways. Infected MDCK cells exposed to no treatment, oseltamivir, silver NPs, and oseltamivir delivered by silver NPs achieved a cell viability of $39 \%, 59 \%, 65 \%$, and $90 \%$, respectively. These results indicate that the antiviral activity of currently prescribed antiviral drugs is effectively strengthened when conjugated with metal NPs. Each of these studies also revealed that the antiviral drugs conjugated with NPs used blocking of the H1N1 from infecting MDCK cells, preventing caspase-3 activity and inhibiting viral accumulation of ROS as antiviral mechanisms of action [144, 145].

"FluPep" is an established peptide inhibitor of influenza type-A virus; however, silver and gold peptide (FluPep) NPs were synthesized and tested for enhanced antiviral activity [146]. Silver and gold NPs functionalized with FluPep ligand (0.03\%) showed inhibition (50\%) against the influenza A virus strain at concentrations of $0.14 \mathrm{nM}$ and $0.073 \mathrm{nM}$, respectively. Most importantly, the study demonstrated that conjugation of FluPep to silver and gold NPs enhanced its antiviral potency compared with the free peptides and are capable of targeting both influenza and bacterial co-infections [146]. Although these results suggest that functionalized NPs are useful antiviral agents against influenza, researchers have also found that non-functionalized metal NPs (i.e., silver) can be effective as well [147-150].

Silver NPs synthesized with Panax ginseng root extract using the sonication method exhibited antiviral activity against the influenza $\mathrm{A}$ virus (strain $\mathrm{A} / \mathrm{PR} / 8$ ) [150]. Low anti-influenza activity was identified at NP concentrations of $0.005,0.01$, and $0.15 \mathrm{M}$, with inhibitory rates of $5.31 \%$, $4.18 \%$, and $5.97 \%$, respectively. However, the anti-influenza effects improved by $7.10 \%$ and $15.12 \%$, with concentrations of 0.02 and $0.25 \mathrm{M}$, respectively [150]. Silver NPs with extracts from cinnamon (bark) demonstrated antiviral activity against the highly pathogenic avian influenza virus subtype H7N3. The NP concentration that inhibited $50 \%$ of infectivity was $125 \mu \mathrm{g} / \mathrm{mL}$. Additional findings revealed that active constituents in the cinnamon bark extract interacted with the virus to interfere with viral replication and inhibit viral entry into the host cell [147].

Xiang et al. [148] confirmed that silver NPs at $50 \mu \mathrm{g} / \mathrm{mL}$ exerted maximum anti-H1N1 influenza A virus activity. Additional findings revealed that the silver ions from the NPs inhibited viral growth by DNA interference, suppression of respiratory enzymes, and electron transport components [148]. Xiang et al. [149] also reported that silver NPs at a concentration of $50 \mu \mathrm{g} / \mathrm{mL}$ demonstrated significant antiviral activity against the $\mathrm{H} 3 \mathrm{~N} 2$ influenza virus (A/Human/Hubei/3/ 2005 strain). These results indicate that functionalized and green synthesized silver NPs could be promising antiinfluenza therapeutics.

\section{Norovirus}

Noroviruses are positive-strand RNA viruses and highly contagious. Globally, it is an established etiological agent in acute gastroenteritis outbreaks affecting all age groups. The infection causes a sudden onset of vomiting, diarrhea, abdominal pain, and cramps after contact with contaminated food or infected individuals [151]. Norovirus can be life-threatening to children, especially undernourished children from developing countries [152], infants, older adults, and immunocompromised individuals [151]. There are no clinically approved antivirals and vaccines for norovirus infections [153] since the challenge is that the virus presents with a vast genetic diversity, with over thirty different genotypes infecting humans [151].

Metal NPs have been reported to exhibit antiviral activity against surrogate models for human norovirus. Broglie et al. [154] produced gold NPs as cores and coated them with copper sulfide nanoshell to inactivate human norovirus-like particles. These NPs at concentrations of $0.083 \mu \mathrm{M}$ and $1.66 \mu \mathrm{M}$ inactivated $50 \%$ and $100 \%$ of the human norovirus virus-like particles, respectively, within a treatment period of $10 \mathrm{~min}$. In this paper, direct binding of the NPs to the virus and damaging of the capsid were mechanisms used by the NPs to inactivate the viral particles [154]. Agnihothram et al. [155] showed that anatase titanium dioxide NPs $(20 \mu \mathrm{g} / \mathrm{mL})$ reduced cell viability of murine norovirus (MNV)-infected RAW 264.7 macrophages by $50 \%$ and $75 \%$, at $24 \mathrm{~h}$ and $48 \mathrm{~h}$ post-infection respectively. Pfaff et al. [49] reported that exposure to tungsten carbide NPs caused a four-log reduction of MNV within $15 \mathrm{~min}$. Ultimately, their findings also suggested that tungsten carbide NPs may be a promising antiviral agent against norovirus, other non-enveloped, and enveloped viruses [49]. 
Silver NPs are also considered as promising antiviral agents against human norovirus. Bekele et al. [156] revealed that silver NPs of $10 \mathrm{~nm}$, at concentrations of $50 \mu \mathrm{g} / \mathrm{mL}$ and $100 \mu \mathrm{g} / \mathrm{mL}$, effectively reduced the titer of feline calicivirus (FCV), a surrogate for human norovirus, beyond the limit of detection. In this paper, the results also showed that the silver NPs of $75 \mathrm{~nm}$ and $110 \mathrm{~nm}$ presented no significant antiviral effects. Furthermore, treatment with the $10 \mathrm{~nm}$ silver NPs reduced FCV capsid protein by $73 \%$ compared with the $75 \mathrm{~nm}$ and $110 \mathrm{~nm}$ silver NPs [156]. Park et al. [157] observed that a novel magnetic hybrid colloid (MHC) conjugated with silver NPs (AgNP-MHCs) caused a two-log reduction in MNV after treatment for $1 \mathrm{~h}$ [157]. The study also found that these particles damaged the viral coat proteins and nucleic acids [157]. Castro-Mayorga et al. [158] evaluated the efficacy of silver NP-based films for inactivating the FCV and MNV. Results revealed that exposing the FCV to the silver NP films for $24 \mathrm{~h}$, produced 100\% virus inactivation [158]. These evidence-based studies show that metal NPs and their composites can be considered as promising antiviral agents against the human norovirus and agents for disinfectants, food packaging, and contact surface industries.

\section{Poliovirus}

Poliovirus, the causative agent of poliomyelitis (polio), consists of a single-stranded positive-sense RNA genome with 7500 nucleotides. There are three serotypes of the wild poliovirus: serotypes 2 and 3, which were eradicated in 2015 and 2019, respectively, while, serotype 1 remains endemic. The clinical features range from mild cases of respiratory illness, gastroenteritis, and malaise to severe forms of paralysis $[159,160]$. It can affect different age groups but common in children under 5 years old who have not received the vaccination. There is no cure for polio infection. However, vaccination is recommended for all infants, children, and adults to establish lifelong immunity against the disease $[159,161]$.

Silver and tungsten carbide NPs have been investigated for antiviral activity against poliovirus. Electrochemicalsynthesized $7.1 \mathrm{~nm}$ silver NPs of quasi-spherical shape with high purity exhibited anti-poliovirus activity. A concentration of $3.13 \mathrm{ppm}$ reduced the poliovirus infectivity by $50 \%$ within $30 \mathrm{~min}$ [162]. Huy et al. [162] also stated that the size of the synthesized NPs was smaller than that of poliovirus particles $(20-30 \mathrm{~nm})$. Therefore, the NPs could easily interact with the viral particles to inhibit viral binding to the host cells and replication. Pfaff et al. [49] also reported that exposure to tungsten carbide NPs caused a 3.5-log reduction in poliovirus infectivity within $15 \mathrm{~min}$. However, it is unfortunate that research on the use of metal NPs for poliovirus treatment is scanty and warrants further investigation.

\section{Respiratory Syncytial Virus Infection}

Respiratory syncytial virus (RSV), a ubiquitous RNA virus [163], is the leading cause of lower respiratory tract infections in infants and adults $[164,165]$. Severe RSV infections can exist among premature babies, older adults, infants, adults with the chronic pulmonary or circulatory disease, and immunocompromised individuals [166]. RSV is increasingly recognized as a global health priority because it remains a significant cause of death [165]. It is worth mentioning that except for ribavirin, there is no other treatment and licensed vaccines for RSV [164, 165].

Emerging evidence suggests that silver NPs could potentially be a therapeutic application for RSV infections. In a study by Yang et al. [167], curcumin modified silver NPs exhibited significant antiviral activity against the RSV, at concentrations ranging from 0.008 to $0.12 \mathrm{nM}$. Based on mechanistic findings, this study further revealed that the curcumin modified silver NPs attached to the viral envelope glycoproteins directly and interfered with the infectivity of RSV [167]. In another cell culture analysis, Morris et al. [168] found that polyvinylpyrrolidone (PVP)-coated silver NPs at a dose of 50 $\mu \mathrm{g} / \mathrm{mL}$ decreased RSV replication by $79 \%$ and $78 \%$ in A549 and HEp-2 cells respectively. Similar antiviral mechanisms of action were noted by Morris et al. [168]. Hence, metal NPs, particularly silver, as antiviral agents for RSV, embrace great potential for future research.

\section{Rift Valley Fever Virus}

Rift Valley fever (RVF) virus is a zoonotic mosquitoborne virus, consisting of a three-segment genome of single-stranded RNA $[169,170]$. It is associated with periodic epidemics of perinatal deaths and abortions in livestock (i.e., cattle, sheep, and goats), an acute febrile illness, encephalitis, retinitis, blindness, neurological disorders, and hemorrhagic syndrome in humans [171, 172]. RVF is endemic in sub-Saharan African countries, including South Africa [173]. Vaccines that are essential for the containment of RVF outbreaks and antiviral drugs for the effective treatment of RVF are currently unavailable [170]. Thus, research has advanced into investigating the potential application of silver NPs to control RVF infection. Borrego et al. [174] demonstrated that metallic silver NPs at a concentration of $12 \mu \mathrm{g} / \mathrm{mL}$ eradicated viral propagation, resulting in a $98 \%$ reduction of viral infectivity. This study also reported that the interaction of silver NPs with the RVF virus affects its infectivity, perhaps by interfering with the virus-cell attachment and viral entry [174]. Further investigations on the application of silver NPs and other metal NPs against RVF infectivity will help combat infection. 


\section{Rubeola Virus}

Rubeola virus is known as the causative agent of measles. This virus is enveloped with a single-stranded negative-sense RNA and spreads through the respiratory route. Measles is highly contagious with clinical symptoms, including skin rash, fever, cough, coryza, and conjunctivitis [175]. A safe and cost-effective vaccine is available. However, measles is still associated with high mortality rates worldwide, particularly in developing countries with inadequate vaccination and health care facilities. No specific antiviral exists for the treatment of measles. Therefore, HIV-infected children, unvaccinated children, pregnant women, and a vaccinated individual who did not develop immunity are at the highest risk of measles and its complications [176]. A study by MeléndezVillanueva et al. [177] reported that gold NPs synthesized with garlic extract from Allium sativa exhibited antiviral activity against the measles virus at an $\mathrm{EC}_{50}$ concentration of $8.829 \mu \mathrm{g} / \mathrm{mL}$. This study also proposed that the gold NPs displayed virucidal effects by directly blocking viral receptors. Gold NPs may be a promising strategy for the treatment of measles, therefore warrants further investigation.

\section{Future Perspectives}

Over fifty nanopharmaceuticals have received FDA approval since 1995 that is currently available for clinical use. These include polymeric, liposomal, nanocrystal formulations, micelles, and inorganic (metal) NPs. The first FDA-approved nanoformulation drug was Doxia (doxorubicin hydrochloride, Janssen) to treat Kaposi's sarcoma in HIV patients [179-181].

Metal NPs have significant potential to increase the pharmaceutical market growth and improve health benefits for viral diseases. However, the current scientific research, preclinical and clinical translation, and regulatory gap for nanomedicines are vast and challenging. Notably, from the outset of metal NP design, it is critical to consider the physicochemical features of different metal NPs, disease pathophysiology, and heterogeneity. Researchers considering these abovementioned factors can assist in tailoring metal NPs with optimal therapeutic benefits. These considerations will also help overcome biological barriers, such as improved targeting and reduced accumulation in non-targeted cells, tissues, and organs. Pre-clinical evaluation for therapeutic efficacy, safety, biodistribution, and pharmacokinetics in appropriate animal models of the disease, relevant to the human condition, is necessary. Before pre-clinical evaluation, extensive in vitro assays for therapeutic efficacy and nanotoxicity screening is essential. After that, pre-clinical toxicology studies in animal models can predict both short-term and long-term toxicity, as circulation half-lives and drug retention times vary with the type of metal ions used for NP synthesis or encapsulation.
Monitoring the absorption, distribution, metabolism, and excretion of emerging metal NPs in vivo is also essential to predicting their toxicological safety profile. Additionally, screening of NPs for immunotoxicological and immunomodulation potential is essential since these functional outcomes correlate with tissue uptake and clearance mechanisms [181]. Hence, addressing these issues is critical to safeguard the clinical application of metal NP-based therapeutics for viral infections.

\section{Conclusion}

Therapeutically, metal NPs, as antiviral agents, are proving to be a promising candidate to tackle current treatment challenges in clinical settings for a broad spectrum of viruses. However, translating the large number of in vitro studies displaying the antiviral activity of metal NPs against different viral infections to pre-clinical and clinical applications is scanty or non-existent. Therefore, scientific evidence gained through research addressing these priority areas can help tailor and synthesize clinically translatable nanosized metal particles to treat viral diseases.

Funding The authors would like to thank the College of Health Sciences, University of KwaZulu-Natal and National Health Laboratory Services for financial support.

\section{Compliance with Ethical Standards}

Conflict of Interest The authors declare that they have no conflict of interest.

\section{References}

1. Aderibigbe BA (2017) Metal-based nanoparticles for the treatment of infectious diseases. Molecules 22(8):1370

2. Joob B, Wiwanitkit V (2017) Nanotechnology for health: A new useful technology in medicine. Medi J Dr DY Patil Univ 10(5): 401

3. Prasad M, Lambe UP, Brar B, Shah I, J M, Ranjan K, Rao R, Kumar S, Mahant S, Khurana SK, Iqbal HMN, Dhama K, Misri J, Prasad G (2018) Nanotherapeutics: an insight into healthcare and multi-dimensional applications in medical sector of the modern world. Biomed Pharmacother 97:1521-1537

4. Nikalje AP (2015) Nanotechnology and its applications in medicine. Med Chem 5(2):081-089

5. Anselmo AC, Mitragotri S (2016) Nanoparticles in the clinic. Bioeng Translat Med 1(1):10-29

6. Galdiero S, Falanga A, Vitiello M, Cantisani M, Marra V, Galdiero M (2011) Silver nanoparticles as potential antiviral agents. Molecules 16(10):8894-8918

7. Khandel P, Yadaw RK, Soni DK, Kanwar L, Shahi SK (2018) Biogenesis of metal nanoparticles and their pharmacological applications: present status and application prospects. J Nanostruct Chemistry 8(3):217-254 
8. Odularu AT (2018) Metal nanoparticles: thermal decomposition, biomedicinal applications to cancer treatment, and future perspectives. Bioinorg Chem Appl 2018:9354708

9. Dhand C, Dwivedi N, Loh XJ, Jie Ying AN, Verma NK, Beuerman RW, Lakshminarayanan R, Ramakrishna S (2015) Methods and strategies for the synthesis of diverse nanoparticles and their applications: a comprehensive overview. RSC Adv 5(127):105003-105037

10. Yu C-H, Tam K, Tsang ES (2008) Chemical methods for preparation of nanoparticles in solution. Handb Metal Phys 5:113-141

11. Deepak P et al. (2019) Chemical and green synthesis of nanoparticles and their efficacy on cancer cells, in Green synthesis, characterization and applications of nanoparticles. Micro and Nano Technologies:369-387

12. Oliveira MM, Ugarte D, Zanchet D, Zarbin AJG (2005) Influence of synthetic parameters on the size, structure, and stability of dodecanethiol-stabilized silver nanoparticles. J Colloid Interface Sci 292(2):429-435

13. Patel P et al (2015) Plant-based synthesis of silver nanoparticles and their characterization. Nanotechnol Plant Sci:271-288

14. Pantidos N (2014) Biological synthesis of metallic nanoparticles by bacteria, fungi and plants. J Nanomed Nanotechnol 5(5):1-10

15. Ingale AG, Chaudhari AN (2013) Biogenic synthesis of nanoparticles and potential applications: an eco-friendly approach. J Nanomed Nanotechol 4(165):1-7

16. Duan H, Wang D, Li Y (2015) Green chemistry for nanoparticle synthesis. Chem Soc Rev 44(16):5778-5792

17. Shah M, Fawcett D, Sharma S, Tripathy S, Poinern G (2015) Green synthesis of metallic nanoparticles via biological entities. Materials 8(11):7278-7308

18. Fang $X$ et al (2019) Microorganism assisted synthesized nanoparticles for catalytic applications. Energies 12(1):1-21

19. Zhang $\mathrm{Y}$ et al (2018) Application of plant viruses as a biotemplate for nanomaterial fabrication. Molecules 23(9):1-20

20. Young M, Debbie W, Uchida M, Douglas T (2008) Plant viruses as biotemplates for materials and their use in nanotechnology. Annu Rev Phytopathol 46:361-384

21. Biazar E, Majdi, Zafari M, Avar M, Aminifard S, Zaeifi D, Ai, Jafarpour, Montazeri, Gh (2011) Nanotoxicology and nanoparticle safety in biomedical designs. Int J Nanomedicine 6:1117-1127

22. Kvitek L et al (2019) Physicochemical aspects of metal nanoparticle preparation, in Silver nanoparticles-health and safety. IntechOpen. https://www.intechopen.com/books/engineerednanomaterials-health-and-safety/physicochemical-aspects-ofmetal-nanoparticle-preparation

23. Adekoya JA et al (2018) Band structure, morphology, functionality, and size-dependent properties of metal nanoparticles, in Noble and precious metals: properties, nanoscale effects and applications. IntechOpen:15-42

24. Abdussalam-Mohammed W (2020) Comparison of chemical and biological properties of metal nanoparticles ( $\mathrm{Au}, \mathrm{Ag}$ ), with metal oxide nanoparticles ( $\mathrm{ZnO}-\mathrm{NPs}$ ) and their applications. Adv J Chem Sect A 3(2):111-236 p. 192-210

25. Guo D, Xie G, Luo J (2013) Mechanical properties of nanoparticles: basics and applications. J Phys D Appl Phys 47(1):013001

26. Andersson MS, Mathieu R, Normile PS, Lee SS, Singh G, Nordblad P, de Toro JA (2017) Magnetic properties of nanoparticle compacts with controlled broadening of the particle size distribution. Phys Rev B 95(18):184431

27. Panáček A, Prucek R, Hrbáč J, Nevečná T’, Šteffková J, Zbořil R, Kvítek L (2014) Polyacrylate-assisted size control of silver nanoparticles and their catalytic activity. Chem Mater 26(3):13321339

28. Cuenya BR, Behafarid F (2015) Nanocatalysis: size-and shapedependent chemisorption and catalytic reactivity. Surf Sci Rep $70(2): 135-187$
29. Suchomel P et al (2018) Simple size-controlled synthesis of Au nanoparticles and their size-dependent catalytic activity. Sci Rep $8(1): 1-11$

30. Zhao P, Feng X, Huang D, Yang G, Astruc D (2015) Basic concepts and recent advances in nitrophenol reduction by gold-and other transition metal nanoparticles. Coord Chem Rev 287:114 136

31. Chaturvedi S, Dave PN, Shah N (2012) Applications of nanocatalyst in new era. J Saudi Chem Soc 16(3):307-325

32. Foroozandeh P, Aziz AA (2018) Insight into cellular uptake and intracellular trafficking of nanoparticles. Nanoscale Res Lett 13(1):339

33. San KA, Shon Y-S (2018) Synthesis of alkanethiolate-capped metal nanoparticles using alkyl thiosulfate ligand precursors: a method to generate promising reagents for selective catalysis. Nanomaterials 8(5):346

34. Jiang W, Kim BYS, Rutka JT, Chan WCW (2008) Nanoparticlemediated cellular response is size-dependent. Nat Nanotechnol 3(3):145-150

35. Banerjee A, Qi J, Gogoi R, Wong J, Mitragotri S (2016) Role of nanoparticle size, shape and surface chemistry in oral drug delivery. J Control Release 238:176-185

36. Rai M, Deshmukh SD, Ingle AP, Gupta IR, Galdiero M, Galdiero S (2016) Metal nanoparticles: the protective nanoshield against virus infection. Crit Rev Microbiol 42(1):46-56

37. Engin AB, Hayes AW (2018) The impact of immunotoxicity in evaluation of the nanomaterials safety. Toxicol Res Appl 2: 2397847318755579

38. Kononenko V, Narat M, Drobne D (2015) Nanoparticle interaction with the immune system/Interakcije nanodelcev z imunskim sistemom. Arch Ind Hyg Toxicol 66(2):97-108

39. Dobrovolskaia MA, Shurin M, Shvedova AA (2016) Current understanding of interactions between nanoparticles and the immune system. Toxicol Appl Pharmacol 299:78-89

40. Pandey RK, Prajapati VK (2018) Molecular and immunological toxic effects of nanoparticles. Int J Biol Macromol 107:12781293

41. Look M, Bandyopadhyay A, Blum JS, Fahmy TM (2010) Application of nanotechnologies for improved immune response against infectious diseases in the developing world. Adv Drug Deliv Rev 62(4-5):378-393

42. Dobrovolskaia MA, McNeil SE (2007) Immunological properties of engineered nanomaterials. Nat Nanotechnol 2(8):469-478

43. Elsabahy M, Wooley KL (2013) Cytokines as biomarkers of nanoparticle immunotoxicity. Chem Soc Rev 42(12):5552-5576

44. Khanal S, Ghimire P, Dhamoon AS (2018) The repertoire of adenovirus in human disease: the innocuous to the deadly. Biomedicines 6(1):30

45. Lion T (2014) Adenovirus infections in immunocompetent and immunocompromised patients. Clin Microbiol Rev 27(3):441462

46. Nichols WG, Campbell AJP, Boeckh M (2008) Respiratory viruses other than influenza virus: impact and therapeutic advances. Clin Microbiol Rev 21(2):274-290

47. Chen N, Zheng Y, Yin J, Li X, Zheng C (2013) Inhibitory effects of silver nanoparticles against adenovirus type 3 in vitro. J Virol Methods 193(2):470-477

48. Lysenko V et al (2018) Nanoparticles as antiviral agents against adenoviruses. Adv Nat Sci Nanosci Nanotechnol 9(2):025021

49. Pfaff F, Glück B, Hoyer T, Rohländer D, Sauerbrei A, Zell R (2019) Tungsten carbide nanoparticles show a broad-spectrum virucidal activity against enveloped and nonenveloped model viruses using a guideline-standardized in vitro test. Lett Appl Microbiol 69(4):302-309

50. Singhal T (2020) A review of coronavirus disease-2019 (COVID19). Indian J Pediatr 87:281-286 
51. Nikaeen G, Abbaszadeh S, Yousefinejad S (2020) Application of nanomaterials in treatment, anti-infection and detection of coronaviruses. Nanomedicine 15:1501-1512

52. Sekimukai H, Iwata-Yoshikawa N, Fukushi S, Tani H, Kataoka M, Suzuki T, Hasegawa H, Niikura K, Arai K, Nagata N (2020) Gold nanoparticle-adjuvanted $\mathrm{S}$ protein induces a strong antigenspecific IgG response against severe acute respiratory syndromerelated coronavirus infection, but fails to induce protective antibodies and limit eosinophilic infiltration in lungs. Microbiol Immunol 64(1):33-51

53. Nasrollahzadeh M, Sajjadi M, Soufi GJ, Iravani S, Varma RS (2020) Nanomaterials and nanotechnology-associated innovations against viral infections with a focus on coronaviruses. Nanomaterials 10(6):1072

54. Sportelli MC, Izzi M, Kukushkina EA, Hossain SI, Picca RA, Ditaranto N, Cioffi N (2020) Can nanotechnology and materials science help the fight against SARS-CoV-2? Nanomaterials 10(4): 802

55. Huang X, Li M, Xu Y, Zhang J, Meng X, An X, Sun L, Guo L, Shan X, Ge J, Chen J, Luo Y, Wu H, Zhang Y, Jiang Q, Ning X (2019) Novel gold nanorod-based HR1 peptide inhibitor for middle east respiratory syndrome coronavirus. ACS Appl Mater Interfaces 11(22):19799-19807

56. Du T et al (2018) Glutathione-capped Ag2S nanoclusters inhibit coronavirus proliferation through blockage of viral RNA synthesis and budding. ACS Appl Mater Interfaces 10(5):4369-4378

57. Chen Y-N, Hsueh YH, Hsieh CT, Tzou DY, Chang PL (2016) Antiviral activity of graphene-silver nanocomposites against nonenveloped and enveloped viruses. Int J Environ Res Public Health 13(4):430

58. Balagna C, Perero S, Percivalle E, Nepita EV, Ferraris M (2020) Virucidal effect against Coronavirus SARS-CoV-2 of a silver nanocluster/silica composite sputtered coating. Open Ceram 1: 100006

59. Ventarola D, Bordone L, Silverberg N (2015) Update on handfoot-and-mouth disease. Clin Dermatol 33(3):340-346

60. Wang M, Li J, Yao MX, Zhang YW, Hu T, Carr MJ, Duchêne S, Zhang XC, Zhang ZJ, Zhou H, Tong YG, Ding SJ, Wang XJ, Shi WF (2019) Genome analysis of coxsackievirus A4 isolates from hand, foot, and mouth disease cases in Shandong, China. Front Microbiol 10:1001

61. Kimmis BD, Christopher D, Stephen T (2018) Hand-foot-andmouth disease caused by coxsackievirus A6 on the rise. Cutis 102:353-356

62. Salem BAN et al (2012) Plant-derived nanoparticles enhance antiviral activity against coxsakievirus $\mathrm{B} 3$ by acting on virus particles and vero cells. Digest J Nanomater Biostruct 7(2):737-744

63. Haggag EG et al (2019) Antiviral potential of green synthesized silver nanoparticles of Lampranthus coccineus and Malephora lutea. Int J Nanomedicine 14:6217-6229

64. Zhong J, Xia Y, Hua L, Liu X, Xiao M, Xu T, Zhu B, Cao H (2019) Functionalized selenium nanoparticles enhance the antiEV71 activity of oseltamivir in human astrocytoma cell model. Artif Cells Nanomed Biotechnol 47(1):3485-3491

65. Li Y, Xu T, Lin Z, Wang C, Xia Y, Guo M, Zhao M, Chen Y, Zhu B (2019) Inhibition of enterovirus A71 by selenium nanoparticles interferes with JNK signaling pathways. ACS Omega 4(4):6720 6725

66. Ceballos-Olvera I, Chávez-Salinas S, Medina F, Ludert JE, del Angel RM (2010) JNK phosphorylation, induced during dengue virus infection, is important for viral infection and requires the presence of cholesterol. Virology 396(1):30-36

67. Paiva CN, Bozza MT (2014) Are reactive oxygen species always detrimental to pathogens? Antioxid Redox Signal 20(6):1000 1037
68. Shragai $\mathrm{T}$ et al (2017) Zika and chikungunya: mosquito-borne viruses in a changing world: global change and vectors of chikungunya and Zika. Ann NY Acad Sci:1-17

69. Weaver S (2006) Evolutionary influences in arboviral disease, in Quasispecies: concept and implications for virology. pp 285-314

70. Silva JV Jr et al (2018) A scoping review of Chikungunya virus infection: epidemiology, clinical characteristics, viral cocirculation complications, and control. Acta Trop 188:213-224

71. Gerardin P et al (2008) Multidisciplinary prospective study of mother-to-child chikungunya virus infections on the island of $\mathrm{La}$ Reunion. PLoS Med 5(3):414-423

72. Silva LA, Dermody TS (2017) Chikungunya virus: epidemiology, replication, disease mechanisms, and prospective intervention strategies. J Clin Invest 127(3):737-749

73. Natrajan MS, Rojas A, Waggoner JJ (2019) Beyond fever and pain: diagnostic methods for chikungunya virus. J Clin Microbiol 57(6):e00350-e00319

74. Karthi S, Shivakumar MS (2016) Vector control in chikungunya and other arboviruses. Curr Topics Chikungunya 24:123-130

75. Kaushik S et al (2019) Anti-chikungunya activity of green synthesized silver nanoparticles using carica papaya leaves in animal cell culture model. Asian J Pharm Clin Res 12(6):170-174

76. Sharma V, Kaushik S, Pandit P, Dhull D, Yadav JP, Kaushik S (2019) Green synthesis of silver nanoparticles from medicinal plants and evaluation of their antiviral potential against chikungunya virus. Appl Microbiol Biotechnol 103(2):881-891

77. Kumar R, Sahoo G, Pandey K, Nayak MK, Topno R, Rabidas V, Das P (2018) Virostatic potential of zinc oxide ( $\mathrm{ZnO}$ ) nanoparticles on capsid protein of cytoplasmic side of chikungunya virus. Int J Infect Dis 73:368

78. Selvan SM et al (2018) Green synthesis of copper oxide nanoparticles and mosquito larvicidal activity against dengue, Zika and chikungunya causing vector Aedes aegypti. IET Nanobiotechnol 12(8): 1042-1046

79. Morejón B et al (2018) Larvicidal activity of silver nanoparticles synthesized using extracts of Ambrosia arborescens (Asteraceae) to control Aedes aegypti L.(Diptera: Culicidae). J Nanotechnol 2018:1-9

80. Balaji, S.M. and K. Manjula, Biosynthesis of silver nano composite using agro waste and its larvicidal properties. 2018.

81. Alshehri MA et al (2020) Phytochemical analysis of Rhazya stricta extract and its use in fabrication of silver nanoparticles effective against mosquito vectors and microbial pathogens. Sci Total Environ 700:134443

82. Sudarmani D, Jaya Durkga S, Nagarani N (2018) Effect of silver nanoparticles synthesized from Daemia extensa against the dengue and chikungunya vector, Aedes aegypti. Int J Res Appl Sci Eng Technol 6(VII):529-535

83. Pilaquinga F et al (2019) Green synthesis of silver nanoparticles using Solanum mammosum L. (Solanaceae) fruit extract and their larvicidal activity against Aedes aegypti L. (Diptera: Culicidae). PLoS One 14(10):1-13

84. Benelli G (2016) Green synthesized nanoparticles in the fight against mosquito-borne diseases and cancer-a brief review. Enzym Microb Technol 95:58-68

85. Kumar R et al (2020) Dengue fever: a review article. Int J Curr Microbiol App Sci 9(1):1502-1510

86. Khetarpal N, Khanna I (2016) Dengue fever: causes, complications, and vaccine strategies. J Immunol Res 2016:1-14

87. Guzman MG et al (2016) Dengue infection. Nat Rev Dis Primers 2(1):1-25

88. Sharon EA, Velayutham K, Ramanibai R (2018) Biosynthesis of copper nanoparticles using Artocarpus heterophyllus against dengue vector Aedes aegypti. Int J Life Sci Scienti Res eISSN 2455(1716): 1716 
89. Abinaya M, Vaseeharan B, Rekha R, Shanthini S, Govindarajan M, Alharbi NS, Kadaikunnan S, Khaled JM, al-Anbr MN (2019) Microbial exopolymer-capped selenium nanowires-towards new antibacterial, antibiofilm and arbovirus vector larvicides? J Photochem Photobiol B Biol 192:55-67

90. Murugan K, Benelli G, Panneerselvam C, Subramaniam J, Jeyalalitha T, Dinesh D, Nicoletti M, Hwang JS, Suresh U, Madhiyazhagan P (2015) Cymbopogon citratus-synthesized gold nanoparticles boost the predation efficiency of copepod Mesocyclops aspericornis against malaria and dengue mosquitoes. Exp Parasitol 153:129-138

91. Sundararajan B, Kumari BR (2017) Novel synthesis of gold nanoparticles using Artemisia vulgaris L. leaf extract and their efficacy of larvicidal activity against dengue fever vector Aedes aegypti L. J Trace Elem Med Biol 43:187-196

92. Benelli G (2018) Gold nanoparticles-against parasites and insect vectors. Acta Trop 178:73-80

93. Nalini M, Lena M, Sumathi P, Sundaravadivelan C (2017) Effect of phyto-synthesized silver nanoparticles on developmental stages of malaria vector, Anopheles stephensi and dengue vector, Aedes aegypti. Egypt J Basic Appl Sci 4(3):212-218

94. Santhosh S, Yuvarajan R, Natarajan D (2015) Annona muricata leaf extract-mediated silver nanoparticles synthesis and its larvicidal potential against dengue, malaria and filariasis vector. Parasitol Res 114(8):3087-3096

95. Banu AN, Balasubramanian C, Moorthi PV (2014) Biosynthesis of silver nanoparticles using Bacillus thuringiensis against dengue vector, Aedes aegypti (Diptera: Culicidae). Parasitol Res 113(1): 311-316

96. Ghramh HA, al-Ghamdi KM, Mahyoub JA, Ibrahim EH (2018) Chrysanthemum extract and extract prepared silver nanoparticles as biocides to control Aedes aegypti (L.), the vector of dengue fever. J Asia Pac Entomol 21(1):205-210

97. Osanloo $\mathrm{M}$ et al (2019) Larvicidal activity of chemically synthesized silver nanoparticles against Anopheles stephensi. J Pharmaceut Negat Results 10(1):69

98. Jinu U, Rajakumaran S, Senthil-Nathan S, Geetha N, Venkatachalam P (2018) Potential larvicidal activity of silver nanohybrids synthesized using leaf extracts of Cleistanthus collinus (Roxb.) Benth. ex Hook. f. and Strychnos nux-vomica L. nux-vomica against dengue, chikungunya and Zika vectors. Physiol Mol Plant Pathol 101:163-171

99. Deepak P, Sowmiya R, Ramkumar R, Balasubramani G, Aiswarya D, Perumal P (2017) Structural characterization and evaluation of mosquito-larvicidal property of silver nanoparticles synthesized from the seaweed, Turbinaria ornata (Turner) J. Agardh 1848. Artif Cells Nanomed Biotechnol 45(5):990-998

100. Elumalai D, Hemavathi M, Deepaa CV, Kaleena PK (2017) Evaluation of phytosynthesised silver nanoparticles from leaf extracts of Leucas aspera and Hyptis suaveolens and their larvicidal activity against malaria, dengue and filariasis vectors. Parasite Epidemiol Contr 2(4):15-26

101. Ravi R et al (2019) Larvicidal effects of nano-synthesized silver particles from Azolla pinnata extract against Aedes aegypti (Diptera: Culicidae). Int J Innovat Technol Explor Eng 8:753-757

102. Parthiban E, Manivannan N, Ramanibai R, Mathivanan N (2019) Green synthesis of silver-nanoparticles from Annona reticulata leaves aqueous extract and its mosquito larvicidal and antimicrobial activity on human pathogens. Biotechnol Rep 21: e00297

103. Soni N, Prakash S (2014) Green nanoparticles for mosquito control. Sci World J 2014:1-6

104. Vignesh M, Moorthi PV (2017) An overview of naturally synthesized metallic nanoparticles. J Appl Pharmaceut Sci 7(06):229 237
105. Paul AM, Shi Y, Acharya D, Douglas JR, Cooley A, Anderson JF, Huang F, Bai F (2014) Delivery of antiviral small interfering RNA with gold nanoparticles inhibits dengue virus infection in vitro. J Gen Virol 95(Pt 8): 1712-1722

106. Quach QH, Ang SK, Chu JHJ, Kah JCY (2018) Size-dependent neutralizing activity of gold nanoparticle-based subunit vaccine against dengue virus. Acta Biomater 78:224-235

107. Murugan K, Aruna P, Panneerselvam C, Madhiyazhagan P, Paulpandi M, Subramaniam J, Rajaganesh R, Wei H, Alsalhi MS, Devanesan S, Nicoletti M, Syuhei B, Canale A, Benelli G (2016) Fighting arboviral diseases: low toxicity on mammalian cells, dengue growth inhibition (in vitro), and mosquitocidal activity of Centroceras clavulatum-synthesized silver nanoparticles. Parasitol Res 115(2):651-662

108. Murugan K, Dinesh D, Paulpandi M, Althbyani ADM, Subramaniam J, Madhiyazhagan P, Wang L, Suresh U, Kumar PM, Mohan J, Rajaganesh R, Wei H, Kalimuthu K, Parajulee MN, Mehlhorn H, Benelli G (2015) Nanoparticles in the fight against mosquito-borne diseases: bioactivity of Bruguiera cylindrica-synthesized nanoparticles against dengue virus DEN2 (in vitro) and its mosquito vector Aedes aegypti (Diptera: Culicidae). Parasitol Res 114(12):4349-4361

109. Sujitha V, Murugan K, Paulpandi M, Panneerselvam C, Suresh U, Roni M, Nicoletti M, Higuchi A, Madhiyazhagan P, Subramaniam J, Dinesh D, Vadivalagan C, Chandramohan B, Alarfaj AA, Munusamy MA, Barnard DR, Benelli G (2015) Green-synthesized silver nanoparticles as a novel control tool against dengue virus (DEN-2) and its primary vector Aedes aegypti. Parasitol Res 114(9):3315-3325

110. Álvarez DM, Castillo E, Duarte LF, Arriagada J, Corrales N, Farías MA, Henríquez A, Agurto-Muñoz C, González PA (2020) Current antivirals and novel botanical molecules interfering with herpes simplex virus infection. Front Microbiol 11:139

111. Ayoub HH, Chemaitelly H, Abu-Raddad LJ (2019) Characterizing the transitioning epidemiology of herpes simplex virus type 1 in the USA: model-based predictions. BMC Med 17(1):57

112. Crimi S, Fiorillo L, Bianchi A, D'Amico C, Amoroso G, Gorassini F, Mastroieni R, Marino S, Scoglio C, Catalano F, Campagna P, Bocchieri S, de Stefano R, Fiorillo MT, Cicciù M (2019) Herpes virus, oral clinical signs and QoL: systematic review of recent data. Viruses 11(5):463

113. Tavakoli A, Hashemzadeh MS (2020) Inhibition of herpes simplex virus type 1 by copper oxide nanoparticles. J Virol Methods 275:113688

114. Hang X, Peng H, Song H, Qi Z, Miao X, Xu W (2015) Antiviral activity of cuprous oxide nanoparticles against hepatitis $\mathrm{C}$ virus in vitro. J Virol Methods 222:150-157

115. Farouk F, Shebl RI (2018) Comparing surface chemical modifications of zinc oxide nanoparticles for modulating their antiviral activity against herpes simplex virus type-1. Int $\mathrm{J}$ Nanopart Nanotechnol 4(021):1-14

116. Tavakoli A, Ataei-Pirkooh A, MM Sadeghi G, Bokharaei-Salim F, Sahrapour P, Kiani SJ, Moghoofei M, Farahmand M, Javanmard D, Monavari SH (2018) Polyethylene glycol-coated zinc oxide nanoparticle: an efficient nanoweapon to fight against herpes simplex virus type 1. Nanomedicine 13(21):2675-2690

117. Dhanasezhian A et al. (2019) Anti-herpes simplex virus (HSV-1 and HSV-2) activity of biogenic gold and silver nanoparticles using seaweed Sargassum wightii. Indian J Mar Sci 45(08): $1252-1257$

118. Cagno V, Andreozzi P, D'Alicarnasso M, Jacob Silva P, Mueller M, Galloux M, le Goffic R, Jones ST, Vallino M, Hodek J, Weber J, Sen S, Janeček ER, Bekdemir A, Sanavio B, Martinelli C, Donalisio M, Rameix Welti MA, Eleouet JF, Han Y, Kaiser L, Vukovic L, Tapparel C, Král P, Krol S, Lembo D, Stellacci F 
(2018) Broad-spectrum non-toxic antiviral nanoparticles with a virucidal inhibition mechanism. Nat Mater 17(2):195-203

119. Halder A, Das S, Ojha D, Chattopadhyay D, Mukherjee A (2018) Highly monodispersed gold nanoparticles synthesis and inhibition of herpes simplex virus infections. Mater Sci Eng C 89:413-421

120. Orłowski P, Kowalczyk A, Tomaszewska E, Ranoszek-Soliwoda K, Wegrzyn A, Grzesiak J, Celichowski G, Grobelny J, Eriksson K, Krzyzowska M (2018) Antiviral activity of tannic acid modified silver nanoparticles: potential to activate immune response in herpes genitalis. Viruses 10(10):524

121. Hu R et al (2014) Inhibition effect of silver nanoparticles on herpes simplex virus 2. Genet Mol Res 13(3):7022-7028

122. Gaikwad S et al (2013) Antiviral activity of mycosynthesized silver nanoparticles against herpes simplex virus and human parainfluenza virus type 3 . Int J Nanomedicine 8:4303

123. Akbarzadeh A, Kafshdooz L, Razban Z, Dastranj Tbrizi A, Rasoulpour S, Khalilov R, Kavetskyy T, Saghfi S, Nasibova AN, Kaamyabi S, Kafshdooz T (2018) An overview application of silver nanoparticles in inhibition of herpes simplex virus. Artif Cells Nanomed Biotechnol 46(2):263-267

124. Etemadzade M, Ghamarypour A, Zabihollahi R, shabbak G, Shirazi M, Sahebjamee H, Vaziri AZ, Assadi A, Ardestani MS, Shandiz SAS, Aghasadeghi MR (2016) Synthesis and evaluation of antiviral activities of novel sonochemical silver nanorods against HIV and HSV viruses. Asian Pacif J Trop Dis 6(11): 854-858

125. Sadowski I, Hashemi FB (2019) Strategies to eradicate HIV from infected patients: elimination of latent provirus reservoirs. Cell Mol Life Sci 76:3583-3600

126. Pandey A, Galvani AP (2019) The global burden of HIV and prospects for control. Lancet HIV 6(12):e809-e811

127. Eisinger RW, Folkers GK, Fauci AS (2019) Ending the human immunodeficiency virus pandemic: optimizing the prevention and treatment toolkits. Clin Infect Dis 69(12):2212-2217

128. Vijayakumar S, Ganesan S (2012) Gold nanoparticles as an HIV entry inhibitor. Curr HIV Res 10(8):643-646

129. Marradi M, di Gianvincenzo P, Enríquez-Navas PM, MartínezÁvila OM, Chiodo F, Yuste E, Angulo J, Penadés S (2011) Gold nanoparticles coated with oligomannosides of HIV-1 glycoprotein gp 120 mimic the carbohydrate epitope of antibody $2 \mathrm{G} 12$. J Mol Biol 410(5):798-810

130. Soto ER, O'Connell O, Dikengil F, Peters PJ, Clapham PR, Ostroff GR (2016) Targeted delivery of glucan particle encapsulated gallium nanoparticles inhibits HIV growth in human macrophages. J Drug Deliv 2016:1-8

131. Choi S-r, Britigan BE, Narayanasamy P (2017) Ga (III) nanoparticles inhibit growth of both Mycobacterium tuberculosis and HIV and release of interleukin- 6 (IL-6) and IL- 8 in coinfected macrophages. Antimicrob Agents Chemother 61(4):e02505-e02516

132. Ardestani MS, Fordoei AS, Abdoli A, Ahangari Cohan R, Bahramali G, Sadat SM, Siadat SD, Moloudian H, Nassiri Koopaei N, Bolhasani A, Rahimi P, Hekmat S, Davari M, Aghasadeghi MR (2015) Nanosilver based anionic linear globular dendrimer with a special significant antiretroviral activity. J Mater Sci Mater Med 26(5):179

133. Hewlings SJ, Kalman DS (2017) Curcumin: a review of its' effects on human health. Foods 6(10):92

134. Sharma RK, Cwiklinski K, Aalinkeel R, Reynolds JL, Sykes DE, Quaye E, Oh J, Mahajan SD, Schwartz SA (2017) Immunomodulatory activities of curcumin-stabilized silver nanoparticles: efficacy as an antiretroviral therapeutic. Immunol Investig 46(8):833-846

135. Sharma A, Yadav A, Gupta N, Sharma S, Kakkar R, Cwiklinski K, Quaye E, Mahajan SD, Schwartz SA, Kumar Sharma R (2019) Multifunctional mesoporous curcumin encapsulated iron- phenanthroline nanocluster: a new Anti-HIV agent. Colloids Surf B: Biointerfaces 180:289-297

136. Do A, Reau NS (2020) Chronic viral hepatitis: current management and future directions. Hepatol Commun 4(3):329-341

137. Thomas DL (2019) Global elimination of chronic hepatitis. N Engl J Med 380(21):2041-2050

138. Lu L, Sun RW, Chen R, Hui CK, Ho CM, Luk JM, Lau GK, Che CM (2008) Silver nanoparticles inhibit hepatitis B virus replication. Antivir Ther 13(2):253-262

139. Dharmapalan D (2020) Influenza. Indian J Pediatr 87:828-832

140. Paules C, Subbarao K (2017) Influenza. Lancet 390(10095):697708

141. Taubenberger JK, Morens DM (2010) Influenza: the once and future pandemic. Public Health Rep 125(3_suppl):15-26

142. Meseko C, Kumar B, Sanicas M (2018) In: Saxena SK (ed) Preventing zoonotic influenza. Influenza-Therapeutics and Challenges. IntechOpen, London, pp 33-55

143. Kumar R, Nayak M, Sahoo GC, Pandey K, Sarkar MC, Ansari Y, Das VNR, Topno RK, Bhawna, Madhukar M, Das P (2019) Iron oxide nanoparticles based antiviral activity of H1N1 influenza A virus. J Infect Chemother 25(5):325-329

144. Lin Z, Li Y, Gong G, Xia Y, Wang C, Chen Y, Hua L, Zhong J, Tang Y, Liu X, Zhu B (2018) Restriction of H1N1 influenza virus infection by selenium nanoparticles loaded with ribavirin via resisting caspase-3 apoptotic pathway. Int J Nanomedicine 13: 5787-5797

145. Li Y, Lin Z, Zhao M, Xu T, Wang C, Hua L, Wang H, Xia H, Zhu B (2016) Silver nanoparticle based codelivery of oseltamivir to inhibit the activity of the H1N1 influenza virus through ROSmediated signaling pathways. ACS Appl Mater Interfaces 8(37): 24385-24393

146. Alghrair ZK, Fernig DG, Ebrahimi B (2019) Enhanced inhibition of influenza virus infection by peptide-noble-metal nanoparticle conjugates. Beilstein J Nanotechnol 10(1):1038-1047

147. Fatima M, Zaidi NUSS, Amraiz D, Afzal F (2016) In vitro antiviral activity of Cinnamomum cassia and its nanoparticles against H7N3 influenza a virus. J Microbiol Biotechnol 26(1):151-159

148. Xiang D, Chen Q, Pang L, Zheng CL (2011) Inhibitory effects of silver nanoparticles on H1N1 influenza A virus in vitro. J Virol Methods 178(1-2):137-142

149. Xiang D et al (2013) Inhibition of $A / H u m a n / H u b e i / 3 / 2005$ (H3N2) influenza virus infection by silver nanoparticles in vitro and in vivo. Int $\mathrm{J}$ Nanomedicine 8:4103

150. Sreekanth T et al (2018) Ultra-sonication-assisted silver nanoparticles using Panax ginseng root extract and their anti-cancer and antiviral activities. J Photochem Photobiol B Biol 188:6-11

151. Parra GI (2019) Emergence of norovirus strains: a tale of two genes. Virus Evolut 5(2):vez048

152. Mans J (2019) Norovirus infections and disease in lower-middleand low-income countries, 1997-2018. Viruses 11(4):341

153. Netzler NE, Enosi Tuipulotu D, White PA (2019) Norovirus antivirals: where are we now? Med Res Rev 39(3):860-886

154. Broglie JJ et al (2015) Antiviral activity of gold/copper sulfide core/shell nanoparticles against human norovirus virus-like particles. PLoS One 10(10):1-14

155. Agnihothram S, Mullis L, Townsend TA, Watanabe F, Mustafa T, Biris A, Manjanatha MG, Azevedo MP, United States Food and Drug Administration, National Center for Toxicological Research (2016) Titanium dioxide nanoparticles evoke proinflammatory response during Murine norovirus infection despite having minimal effects on virus replication. Int J Nanotechnol Med Eng 1(3):6373

156. Bekele AZ, Gokulan K, Williams KM, Khare S (2016) Dose and size-dependent antiviral effects of silver nanoparticles on feline calicivirus, a human norovirus surrogate. Foodborne Pathog Dis 13(5):239-244 
157. Park S, Park HH, Kim SY, Kim SJ, Woo K, Ko GP (2014) Antiviral properties of silver nanoparticles on a magnetic hybrid colloid. Appl Environ Microbiol 80(8):2343-2350

158. Castro-Mayorga JL, Randazzo W, Fabra MJ, Lagaron JM, Aznar R, Sánchez G (2017) Antiviral properties of silver nanoparticles against norovirus surrogates and their efficacy in coated polyhydroxyalkanoates systems. LWT-Food Sci Technol 79: 503-510

159. Mamun $\mathrm{KZ}$ et al (2020) Moving from oral poliovirus vaccine to inactivated poliovirus vaccine: the rationale and challenges. Bangladesh J Med 31(1):22-28

160. Ghafoor S, Sheikh N (2016) Eradication and current status of poliomyelitis in Pakistan: ground realities. J Immunol Res 2016: $1-6$

161. Ali SA et al (2015) Polio-an endemic disease in Pakistan: literature review. i-manager's J Nurs 5(1):29

162. Huy TQ, Hien Thanh NT, Thuy NT, Chung PV, Hung PN, le AT, Hong Hanh NT (2017) Cytotoxicity and antiviral activity of electrochemical-synthesized silver nanoparticles against poliovirus. J Virol Methods 241:52-57

163. Lanari M, Vandini S, Capretti MG, Lazzarotto T, Faldella G (2014) Respiratory syncytial virus infections in infants affected by primary immunodeficiency. J Immunol Res 2014:1-6

164. Meng J et al (2014) An overview of respiratory syncytial virus. PLoS Pathog 10(4):1-4

165. Nam HH, Ison MG (2019) Respiratory syncytial virus infection in adults. bmj 366:15021

166. Griffiths C, Drews SJ, Marchant DJ (2017) Respiratory syncytial virus: infection, detection, and new options for prevention and treatment. Clin Microbiol Rev 30(1):277-319

167. Yang XX, Li CM, Huang CZ (2016) Curcumin modified silver nanoparticles for highly efficient inhibition of respiratory syncytial virus infection. Nanoscale 8(5):3040-3048

168. Morris D, Ansar M, Speshock J, Ivanciuc T, Qu Y, Casola A, Garofalo R (2019) Antiviral and immunomodulatory activity of silver nanoparticles in experimental RSV infection. Viruses 11(8): 732

169. Lumley S, Horton DL, Hernandez-Triana LLM, Johnson N, Fooks AR, Hewson R (2017) Rift valley fever virus: strategies for maintenance, survival and vertical transmission in mosquitoes. J Gen Virol 98(5):875-887

170. Javelle E, Lesueur A, Pommier de Santi V, de Laval F, Lefebvre T, Holweck G, Durand GA, Leparc-Goffart I, Texier G, Simon F (2020) The challenging management of Rift Valley Fever in humans: literature review of the clinical disease and algorithm proposal. Ann Clin Microbiol Antimicrob 19(1):4

171. Ikegami T, Makino S (2011) The pathogenesis of Rift Valley fever. Viruses 3(5):493-519

172. Njenga MK, Bett B (2019) Rift Valley fever virus - how and where virus is maintained during inter-epidemic periods. Curr Clin Microbiol Rep 6(1):18-24

173. Jansen van Vuren P et al (2018) Human cases of Rift Valley fever in South Africa, 2018. Vector-Borne Zoonotic Dis 18(12):713715

174. Borrego B, Lorenzo G, Mota-Morales JD, Almanza-Reyes H, Mateos F, López-Gil E, de la Losa N, Burmistrov VA, Pestryakov AN, Brun A, Bogdanchikova N (2016) Potential application of silver nanoparticles to control the infectivity of Rift Valley fever virus in vitro and in vivo. Nanomedicine 12(5):11851192

175. Griffin DE (2014) Measles virus and the nervous system. In: Handbook of clinical neurology. 123:577-590

176. Naim HY (2015) Measles virus: a pathogen, vaccine, and a vector. Human Vacc Immunotherapeut 11(1):21-26

177. Meléndez-Villanueva MA, Morán-Santibañez K, MartínezSanmiguel JJ, Rangel-López R, Garza-Navarro MA, RodríguezPadilla C, Zarate-Triviño DG, Trejo-Ávila LM (2019) Virucidal activity of gold nanoparticles synthesized by green chemistry using garlic extract. Viruses 11(12):1111

178. Kumar SD, Singaravelu G, Ajithkumar S, Murugan K, Nicoletti M, Benelli G (2017) Mangrove-mediated green synthesis of silver nanoparticles with high HIV-1 reverse transcriptase inhibitory potential. J Clust Sci 28(1):359-367

179. Ventola CL (2017) Progress in nanomedicine: approved and investigational nanodrugs. Pharm Therapeut 42(12):742-755

180. Cojocaru F-D, Botezat D, Gardikiotis I, Uritu CM, Dodi G, Trandafir L, Rezus C, Rezus E, Tamba BI, Mihai CT (2020) Nanomaterials designed for antiviral drug delivery transport across biological barriers. Pharmaceutics 12(2):171

181. Hua S, de Matos MBC, Metselaar JM, Storm G (2018) Current trends and challenges in the clinical translation of nanoparticulate nanomedicines: pathways for translational development and commercialization. Front Pharmacol 9:790

Publisher's Note Springer Nature remains neutral with regard to jurisdictional claims in published maps and institutional affiliations. 